\title{
A taxonomic revision of the Boehmeria spicata complex (Urticaceae) in Korea
}

\author{
Hyeong Jun JO, Jae Young KIM, Yuri LEE', Se Hee PARK, Min Ji KWON, \\ Seon JEONG and Gyu Young CHUNG* \\ Division of Horticulture and Medicinal Plant, Andong National University, Andong 36729, Korea \\ ${ }^{1}$ Graduate School of Science and Technology, Niigata University, Niigata 950-2181, Japan \\ (Received 30 March 2021; Revised 24 May 2021; Accepted 10 June 2021)
}

\begin{abstract}
Seven species and two varieties belonging to the genus Boehmeria Jacq. (Urticaceae) are known to be distributed in Korea. Among them, B. spicata, B. tricuspis, and B. tricuspis var. unicuspis were subjected to an external morphological study. Among the individuals believed to exhibit variations in the leaf shape, $B$. gracilis and B. silvestrii were newly recognized. Unlike related taxa, B. gracilis has middle leaves with an elliptic, broadly elliptic, ovate, or broadly depressed ovate shape, a regular and serrulate-dentate margin, and an unlobed and short caudate or cuspidate apex. Boehmeria silvestrii has middle leaves with 5-angled ovate, orbicular ovate or broadly ovate shapes, and 3- or 5-lobed and caudate apices. Therefore, we assigned the corresponding names 'Top-geo-buk-kko-ri' and 'Cham-geo-buk-kko-ri'. Meanwhile, the B. spicata complex (B. gracilis, B. silvestrii, $B$. spicata, and $B$. tricuspis var. unicuspis) is very closely related in terms of the morphological characters, whereas $B$. tricuspis exhibits no relationship. Furthermore, because the scientific name and type specimen of $B$. tricuspis var. unicuspis (Pul-geo-buk-kko-ri) are problematic, the correct name B. paraspicata Nakai and corresponding holotype are presented. Additionally, lectotypes of $B$. gracilis and B. silvestrii are newly designated here. A taxonomic treatment, descriptions, a key, photographs, type specimens, and leaf variation images of the B. spicata complex are provided in this study.
\end{abstract}

Keywords: Boehmeria, B. gracilis, B. paraspicata, B. silvestrii, B. spicata, lectotypification

The genus Boehmeria Jacq. is one of the largest genera belonging to the family Urticaceae (Gaudichaud, 1830; Weddell, 1856, 1869; Wilmot-Dear and Friis, 2013). The genus is composed of approximately 100-150 species and is distributed in the tropics and subtropics (East Africa, Indian Ocean Islands, East to West Asia, Oceania, Pacific Ocean Islands, and North to South America). In particular, many species are distributed from the Himalayas to Indochina (Weddell, 1856; Blume, 1857; Jackson, 1895; Pinner and Bence, 1987; Ilvessalo-Pfäffli, 1995; Wilmot-Dear and Friis, 1996, 2013; Kozłowski, 2012). Approximately 44-75 species of this genus are distributed in Asia (Yahara, 1981; Zhao et al., 2003; Pierozzi et al., 2008). In Korea, seven species and two varieties of this genus are distributed (Liang, 2009; Kim, 2018). Among them, B. spicata
(Thunb.) Thunb., B. tricuspis (Hance) Makino, and B. tricuspis var. unicuspis Makino are the most confusing, as the boundary of the leaf variation is unclear.

Meanwhile, B. tricuspis is generally confused with $B$. silvestrii (Pamp.) W. T. Wang because the apex of the leaf is similar to a 3-lobed shape (Makino, 1940, 1961, 1989; Ohwi, 1953, 1965; Kitamura and Murata, 1961; Im, 1996; Lee, 1996a, 1996b; Lee, 2003; Tateishi, 2006; Liang, 2009; Wilmot-Dear and Friis, 2013). The distribution of B. silvestrii in Korea was mentioned for the first time by Makino (1989).

Boehmeria gracilis C. H. Wright is also known to be distributed in Korea (Makino, 1989), and it is often confused with B. spicata and B. tricuspis var. unicuspis. In China, Chen et al. (2003) considered B. gracilis and B. tricuspis var.

\footnotetext{
*Author for correspondence: gychung@andong.ac.kr
} 
Table 1. Comparison of the Boehmeria spicata and the related taxa recognized in Korea, China, and Japan.

\begin{tabular}{|c|c|c|c|c|c|c|c|c|c|c|c|}
\hline \multirow[b]{2}{*}{ Taxa } & \multicolumn{4}{|c|}{ Korea } & \multicolumn{2}{|c|}{ China } & \multicolumn{5}{|c|}{ Japan } \\
\hline & $\begin{array}{c}\text { Lee } \\
(1996 a, 1996 b)\end{array}$ & $\begin{array}{l}\text { Lee } \\
(2003)\end{array}$ & $\begin{array}{l}\text { Lee } \\
(2006)\end{array}$ & $\begin{array}{l}\text { Kim } \\
(2018)\end{array}$ & $\begin{array}{c}\text { Chen et al. } \\
\text { (2003) }\end{array}$ & $\begin{array}{l}\text { Wang } \\
(2016)\end{array}$ & $\begin{array}{c}\text { Kitamura and } \\
\text { Murata (1961) }\end{array}$ & $\begin{array}{c}\text { Makino } \\
(1961)\end{array}$ & $\begin{array}{l}\text { Ohwi } \\
\text { (1965) }\end{array}$ & $\begin{array}{l}\text { Makino } \\
(1989)\end{array}$ & $\begin{array}{l}\text { Tateishi } \\
(2006)\end{array}$ \\
\hline B. gracilis & & & & & & 0 & & & & 0 & O \\
\hline B. spicata & 0 & 0 & 0 & 0 & 0 & 0 & 0 & 0 & 0 & 0 & 0 \\
\hline B. tricuspis var. unicuspis & 0 & 0 & 0 & 0 & & & 0 & O & 0 & & \\
\hline
\end{tabular}

unicuspis as synonyms of B. spicata. However, Wang (2016) recently recognized $B$. gracilis and $B$. spicata as independent species and treated $B$. tricuspis var. unicuspis as a synonym of $B$. gracilis. In Japan, B. spicata and B. tricuspis var. unicuspis were treated as different taxa (Kitamura and Murata, 1961; Makino, 1961; Ohwi, 1965). Later, Makino (1989) recognized $B$. tricuspis var. unicuspis as $B$. gracilis and considered B. gracilis and B. spicata as independent species. Tateishi (2006) also treated B. gracilis and B. spicata as independent species. In Korea, B. spicata and B. tricuspis var. unicuspis are recognized as independent taxa (Table 1; Lee, 1996a, 1996b; Lee, 2003; Lee, 2006; Kim, 2018).

Thus, the purpose of this study is to examine the identities of $B$. silvestrii and B. gracilis by comparing them with $B$. spicata and related taxa. Boehmeria gracilis, B. silvestrii, $B$. spicata, and B. tricuspis var. unicuspis are very closely related in terms of the morphological characters, whereas B. tricuspis exhibits no relationship, as noted above. They have common characters as a subshrub or small shrub, a sparsely strigillose or subglabrous plant, with a convex midvein of the leaf on the adaxial surface, a cleft perianth of the male flower, an unbranched pistillate inflorescence, and an irregular strigillose perianth tube of the achene throughout the surface. Accordingly, they are recognized as the B. spicata complex. The situation is taxonomically very confusing due to leaf variations and no distinct difference in the reproductive characters.

Therefore, a taxonomic treatment, descriptions, a key, photographs, type specimens, and leaf variation images are presented based on the original descriptions, type specimens, and morphological characters.

\section{Materials and Methods}

The literature was reviewed and fieldwork was conducted from 2016 to 2020 in Korea. Voucher specimens were deposited in the herbarium of Andong National University (ANH) (Appendix 1). Herbarium specimens of KB, KH, TI, and WFRC and specimen images of BM, FI, GH, K, LD,
LINN, MNHN, P, PE, and UPS were also examined. The qualitative and quantitative morphological characters of the vegetative organs (e.g., habit type, plant hair, leaf shape) and reproductive organs (e.g., inflorescence shape, male flower shape, achene hair) were observed with a microscope (AX-70, Olympus, Tokyo, Japan; DP2-BSW, Olympus) and with a digital caliper (CD-15CPX, Mitutoyo, Kawasaki, Japan).

\section{Taxonomic Treatment}

1. Boehmeria gracilis C. H. Wright, J. Linn. Soc., Bot. 26: 485, 1899.-TYPE: China. Hubei, Patung, Ichang, May 1888, A. Henry 4692 (lectotype: K, photo!, designated here, see Fig. 1A); Hubei, 1885-1888, A. Henry 4692 (syntype: GH, photo!); Hubei, Patung, Ichang, May 1888, A. Henry 4728 (syntype: K, photo!); Hubei, Changlo, Mar 1889, A. Henry 6258 (syntype: K, photo!).

B. tricuspis var. unicuspis Makino, Ill. Fl. Nippon. 641, 1940, nom. nud:; B. tricuspis var. unicuspis Makino ex Ohwi, Fl. Jap. 441, 1953.

Korean name: Top-geo-buk-kko-ri (톱거북꼬리, new common name).

Habits subshrub, monoecious or dioecious. Stems erect, 0.5-1.3 m tall, 1.5-3.2 mm in diam., a few branched from the base, red or green, sparsely strigillose or subglabrous. Leaves opposite, pairs subequal in size; stipules lanceolate, 7.2-12.6 $\mathrm{mm}$ long, 1.9-2.9 mm wide, yellow green, sparsely pubescent along midvein on abaxial surface; petioles $1.1-9.0 \mathrm{~cm}$ long, $0.6-1.9 \mathrm{~mm}$ in diam., red or green, sparsely strigillose or subglabrous; middle leaf blades elliptic, broadly elliptic, ovate or broadly depressed ovate, $3.8-13.7 \mathrm{~cm}$ long, 3.3-10.6 cm wide, base cuneate, broadly cuneate or subtruncate, margin serrulate-dentate, gradually subequal distally, teeth $7-15$ on each side, narrowly triangular to triangular, 4.3-6.6 mm long, 5.6-9.3 mm wide, apex unlobed, short caudate or cuspidate, adaxial surface green, sparsely strigillose, densely cystoliths punctiform, midvein convex, abaxial surface yellow green, sparsely strigillose with uncinate hair or subglabrous along 


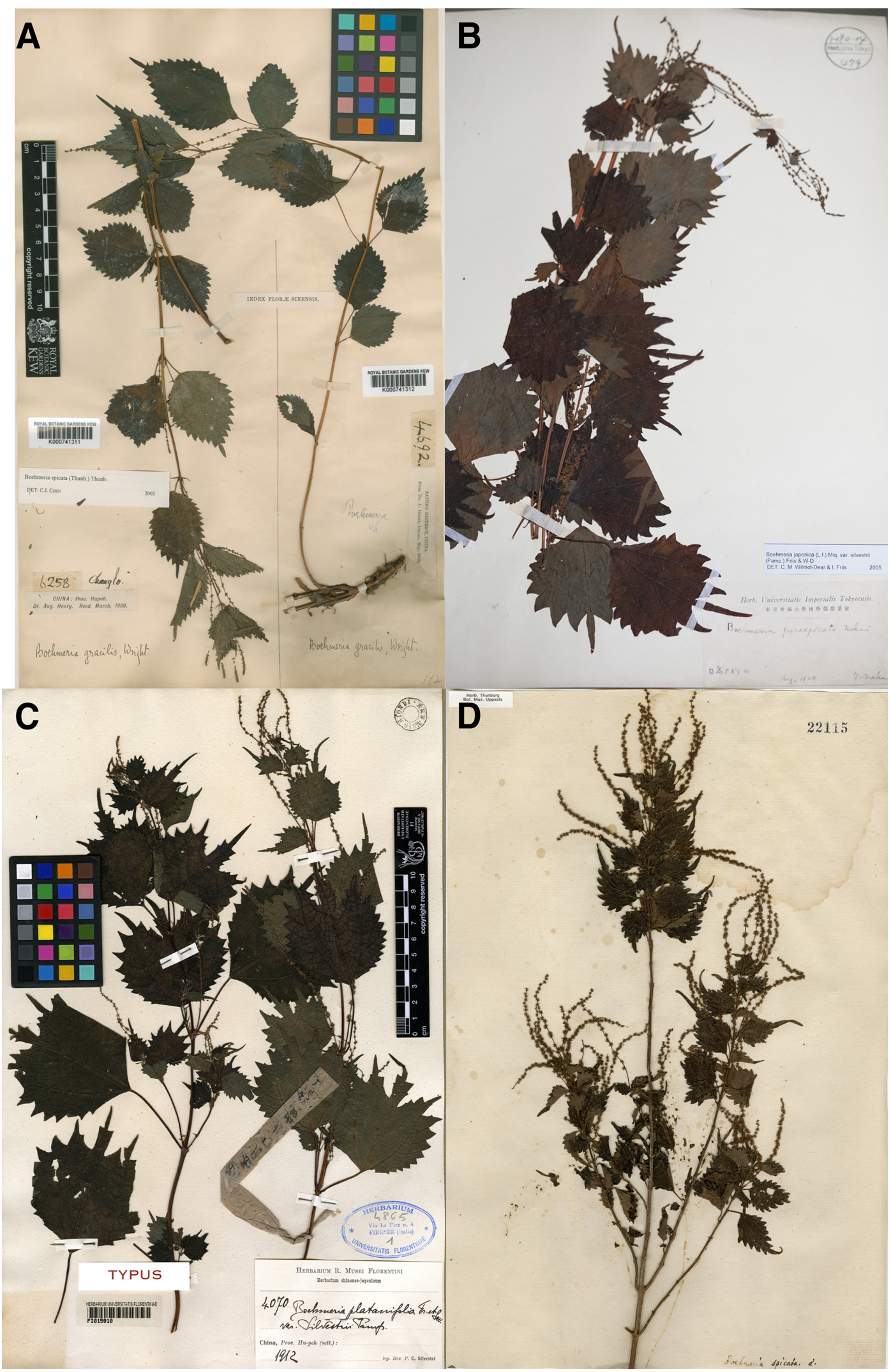

Fig. 1. Types of the Boehmeria spicata complex. A. B. gracilis (lectotype: A. Henry, 4692, K, designated here). B. B. paraspicata (holotype: $T$. Nakai s.n., TI). C. B. silvestrii (lectotype: P. C. Silvestri 4070, FI, designated here). D. B. spicata (lectotype: C. P. Thunberg 22115, UPS) 
veins and veinlets, often thin membranous or chartaceous. Inflorescences axillary; staminate inflorescences unbranched or branched in proximal axils, $15.5-17.2 \mathrm{~cm}$ long, rachis 1.0 $1.3 \mathrm{~mm}$ in diam.; pistillate inflorescences unbranched in distal axils, 7.7-18.1 cm long, rachis $0.3-0.5 \mathrm{~mm}$ in diam., loosely glomerules at flowering, relatively densely glomerules at fruiting. Flowers unisexual; male flowers 4-merous, rarely 3or 5-merous, 3.1-4.9 $\mathrm{mm}$ in diam.; pedicels $0.2-1.2 \mathrm{~mm}$ long, red or green; perianth lobes cleft near to the middle, convex, elliptic, $0.9-1.2 \mathrm{~mm}$ long, $1.0-1.2 \mathrm{~mm}$ wide, red or yellow green, strigillose in outside; filaments 4 , rarely 3 or 5 , linear, inflexed, 3.1-4.9 mm long, white; anthers basifixed, 0.8$1.2 \mathrm{~mm}$ long, $0.8-1.2 \mathrm{~mm}$ wide, white; ovaries rudimentary, clavate; female flowers $3.6-4.0 \mathrm{~mm}$ long, sessile; perianth tubes obovoid, $1.0-1.4 \mathrm{~mm}$ long, $0.7-1.6 \mathrm{~mm}$ wide, red or yellow green, strigillose with uncinate hair; necks 2-toothed; styles 1, linear, plumose, 1.9-3.3 mm long, red or white; stamens absent. Achenes rhomboid or obovoid, compressed, 1.4-3.5 mm long, 0.9-2.8 mm wide, base cuneate, irregular strigillose with uncinate hair throughout the surface. Seeds subcircular, $0.7-1.3 \mathrm{~mm}$ long, $0.6-1.0 \mathrm{~mm}$ wide; wings rhomboid, obovoid or broadly obovoid, 1.2-1.4 mm long, 1.0$1.1 \mathrm{~mm}$ wide.

Chromosome number: $2 n=28$ (Yahara, 1983).

Phenology: Flowering July to September, Fruiting September to November.

Distribution: Korea (all provinces except Jejudo and Ulleungdo Islands), China, Japan.

Taxonomic note: This taxon has slight similarity to $B$. spicata but was announced as a new species due to the ovate shape of the leaf and the regular, serrate margin of the leaf by C. H. Wright (Forbes and Hemsley, 1899). Later, Tateishi (2006) and Wang (2016) treated B. tricuspis var. unicuspis as a synonym of $B$. gracilis. Chen et al. (2003) and Wilmot-Dear and Friis (2013) considered B. gracilis and B. tricuspis var. unicuspis as continuous variations of $B$. spicata (Jom-kkae-ipna-mu). Therefore, B. gracilis, B. spicata, and B. tricuspis var. unicuspis are often confused with each other. However, Yahara (1983, 1986) and Wang $(1981,2016)$ recognized B. gracilis as an independent species because it is distinguished from $B$. spicata by the habit, shape, size, margin, and hair of the leaf, as well as the rachis hair of the inflorescence.

Meanwhile, Makino (1940) first published B. tricuspis var. unicuspis based on the red petiole, red inflorescence, and caudate or non-caudate apex of the leaf. In the description, it is written as 'Marubaakaso' in Japanese, which means a form of $B$. tricuspis with a round shape of the leaf. Subsequently, Makino (1989) recognized B. gracilis with the Japanese name
'Kusakoakaso.' In the literature, B. tricuspis var. unicuspis was omitted and B. tricuspis was renamed B. silvestrii, but the description and the illustrated image of $B$. silvestrii were identical to B. tricuspis described by Makino (1940). Therefore, $B$. tricuspis var. unicuspis published by Makino is presumed to be $B$. gracilis, which often has red petioles, a red inflorescence, a round-shaped leaf, and regular teeth. Consequently, B. tricuspis var. unicuspis is treated as a taxonomic synonym in this study.

Because $B$. gracilis is a subshrub with middle leaves that have elliptic, broadly elliptic, ovate, or broadly depressed ovate shapes, a subequal size of the teeth and a serrulate-dentate margin of the leaf, as well as a short caudate or cuspidate apex of the leaf, it can be distinguished from B. spicata (Figs. 2, 3, and Table 2). Therefore, it is named 'Top-geo-buk-kko-ri' based on the subequal size of the teeth and the serrulate-dentate margin of the leaf.

2. Boehmeria paraspicata Nakai, Veg. Mt. Apoi 19, 1930; B. tricuspis (Hance) Makino var. paraspicata (Nakai) Hara, Bot. Mag. (Tokyo) 48: 812, 1934; Duretia paraspicata (Nakai) Nakai, Bull. Natl. Sci. Mus. Tokyo 31: 42, 1952, nom. illeg.; B. tricuspis subsp. paraspicata (Nakai) Kitamura, Col. Ill. Herb. Pl. Jap. 2: 340, 1961.-TYPE: Japan. Hokkaido, Prov. Hidaka, Mt. Apoi, Aug 1928, T. Nakai s.n. (holotype: TI!, see Fig. 1B).

B. paraspicata Nakai ex Satake, J. Fac. Sci. Univ. Tokyo, Sect. 3, Bot. 4: 483, 1936, nom. illeg.-TYPE: Japan. Hokkaido, Prov. Isikari, Kanayama, Aug 1916, G. Koidzumi s.n. (holotype: TI, photo!).

B. paraspicata Nakai f. viridis Satake, J. Fac. Sci. Univ. Tokyo, Sect. 3, Bot. 4: 485, 1936.-Type: Japan. Honshu, Prov. Sagami, Mt. Zinba, 19 Jul 1931, K. Hisauchi s.n. (holotype: TI, photo!).

\section{Korean name: Pul-geo-buk-kko-ri (풀거북꼬리).}

Habits subshrub, monoecious or dioecious. Stems erect, 0.8-1.1 m tall, 1.8-4.1 $\mathrm{mm}$ in diam., a few branched from the base, green or red, sparsely strigillose or subglabrous. Leaves opposite, pairs subequal in size; stipules lanceolate, 8.2$14.7 \mathrm{~mm}$ long, $1.4-3.5 \mathrm{~mm}$ wide, yellow green, sparsely pubescent along midvein on abaxial surface; petioles 3.8-12.1 $\mathrm{cm}$ long, $0.8-1.7 \mathrm{~mm}$ in diam., green or red, sparsely strigillose or subglabrous; middle leaf blades ovate to broadly ovate, 9.0 $19.1 \mathrm{~cm}$ long, 7.4-16.2 cm wide, base broadly cuneate, margin serrate-dentate, gradually larger distally, teeth 6-14 on each side, narrowly triangular to triangular, 6.4-9.9 mm long, 7.2$10.6 \mathrm{~mm}$ wide, apex unlobed, caudate or narrowly acute, adaxial surface green, sparsely strigillose, densely cystoliths 


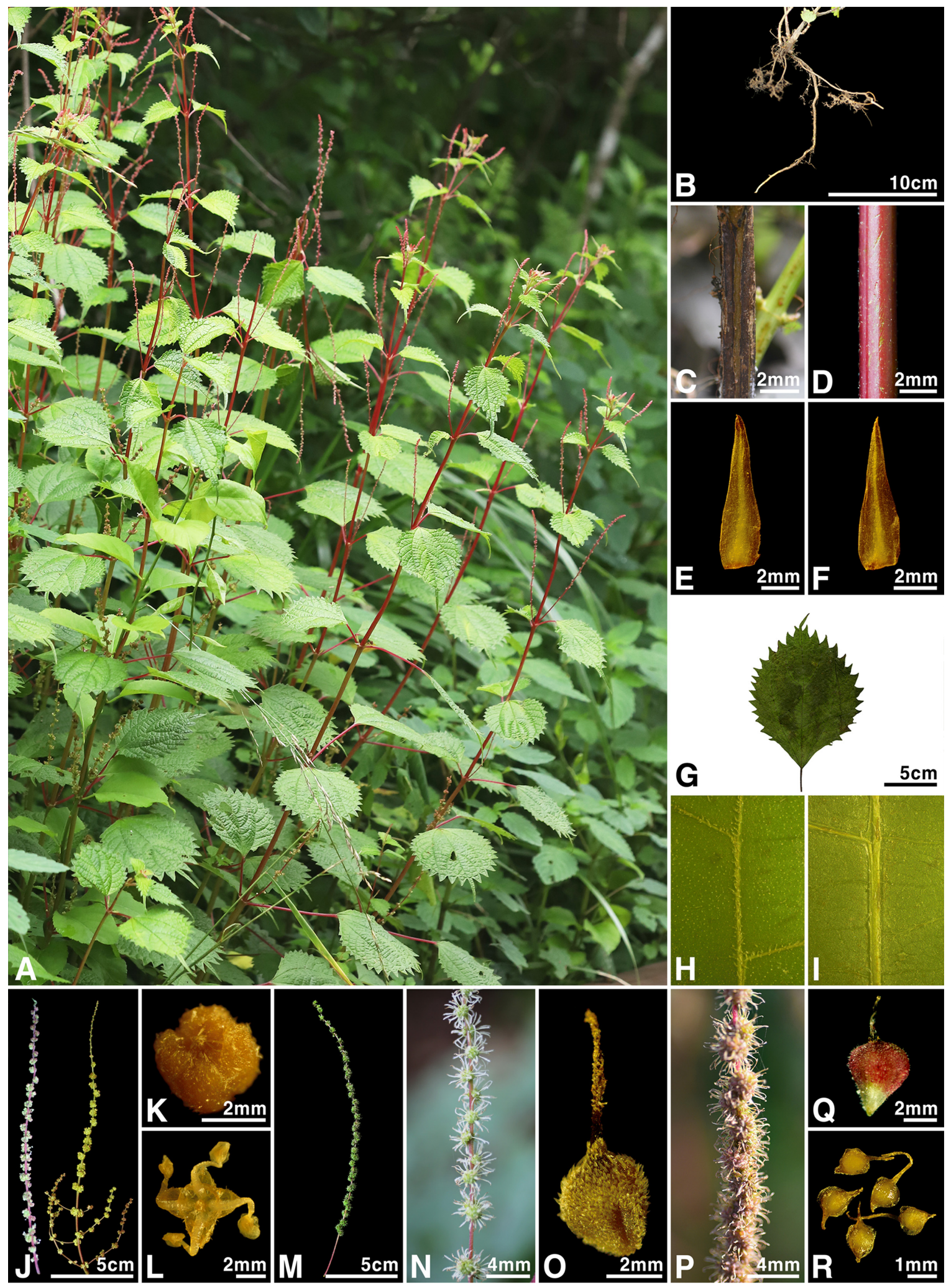

Fig. 2. Photographs of Boehmeria gracilis. A. Habit. B. Underground structure. C. Base stem. D. Middle stem. E. Adaxial surface of stipule. F. Abaxial surface of stipule. G. Middle leaf. H. Adaxial surface of leaf. I. Abaxial surface of leaf. J. Staminate inflorescence (left: unbranched, right: branched). K. Bud of male flower. L. Male flower. M, N. Pistillate inflorescence at flowering. O. Female flower. P. Pistillate inflorescence at fruiting. Q. Achene. R. Seeds. 
A

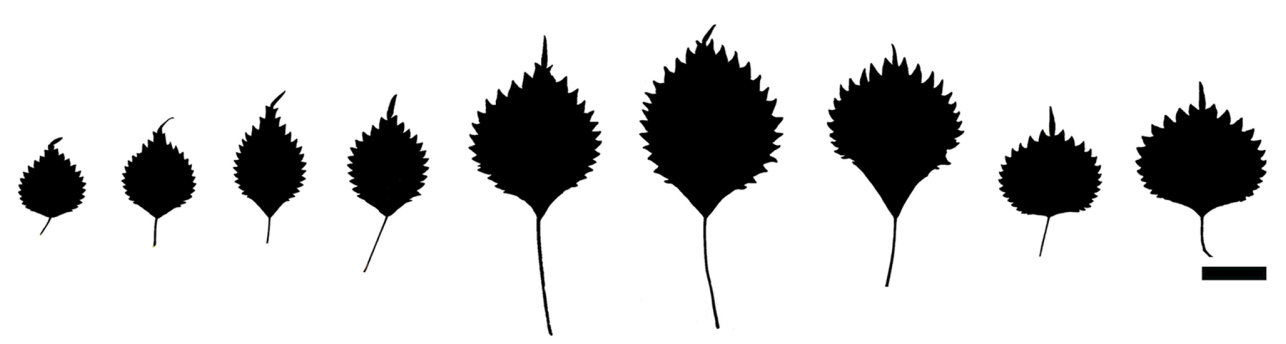

B

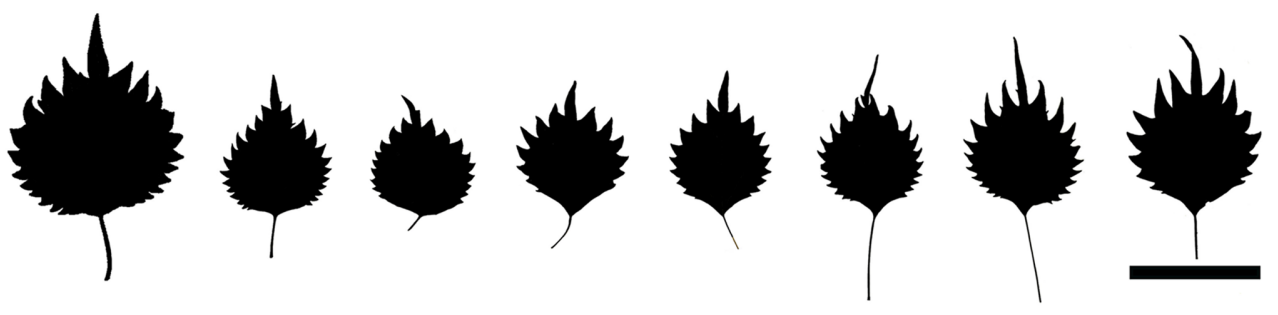

C

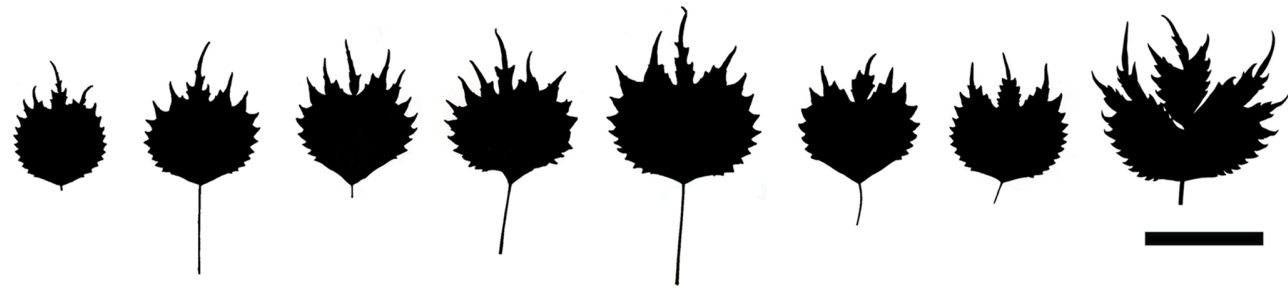

D
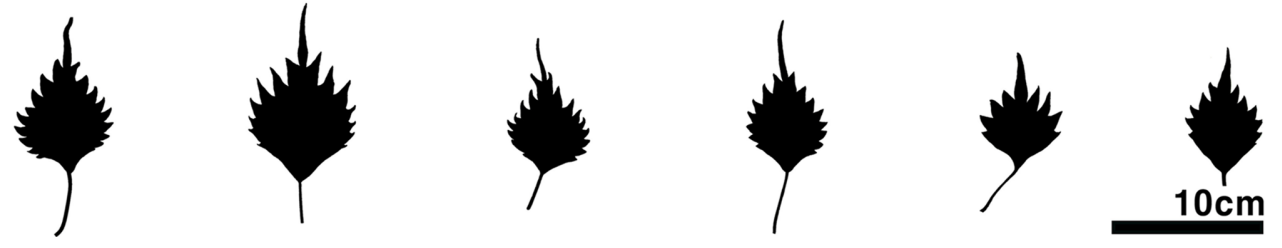

Fig. 3. Middle leaf variations of the Boehmeria spicata complex. A. B. gracilis. B. B. paraspicata. C. B. silvestrii. D. B. spicata.

punctiform, midvein convex, abaxial surface yellow green, sparsely strigillose with uncinate hair or subglabrous along veins and veinlets, often thin membranous or chartaceous. Inflorescences axillary; staminate inflorescences unbranched or rarely branched in proximal axils, 5.9-28.5 cm long, rachis $0.2-1.1 \mathrm{~mm}$ in diam.; pistillate inflorescences unbranched in distal axils, 9.4-23.7 cm long, rachis $0.3-0.9 \mathrm{~mm}$ in diam., loosely glomerules at flowering, relatively densely glomerules at fruiting. Flowers unisexual; male flowers 4-merous, rarely 5-merous, 4.0-5.2 $\mathrm{mm}$ in diam.; pedicels $0.2-1.6 \mathrm{~mm}$ long, green or red; perianth lobes cleft near to the middle, convex, elliptic, 0.9-1.2 mm long, 0.9-1.1 mm wide, yellow green or red, strigillose in outside; filaments 4 , rarely 5 , linear, inflexed, 1.7-2.2 mm long, white; anthers basifixed, 0.7-1.0 mm long, $0.7-0.9 \mathrm{~mm}$ wide, white; ovaries rudimentary, clavate; female flowers 2.6-3.3 mm long, sessile; perianth tubes obovoid, 1.3$1.7 \mathrm{~mm}$ long, $0.6-1.0 \mathrm{~mm}$ wide, yellow green or red, strigillose with uncinate hair; necks 2-toothed; styles 1, linear, plumose, 0.8-2.0 mm long, white or red; stamens absent. Achenes rhomboid or obovoid, compressed, $2.5-4.0 \mathrm{~mm}$ long, 2.2$3.3 \mathrm{~mm}$ wide, base cuneate, irregular strigillose with uncinate hair throughout the surface. Seeds elliptic or subcircular, 1.0 $1.7 \mathrm{~mm}$ long, $0.8-1.6 \mathrm{~mm}$ wide; wings rhomboid-obovoid or broadly obovoid, $0.7-1.0 \mathrm{~mm}$ long, $0.6-0.8 \mathrm{~mm}$ wide.

Chromosome number: $2 n=28$ (Okabe, 1963; Yahara, 1983).

Phenology: Flowering July to September, Fruiting September to November.

Distribution: Korea (all provinces), China, Japan.

Taxonomic note: Nakai (1930) first reported a new species, B. paraspicata Nakai. This name was accompanied by a Japanese diagnosis without a type specimen in the flora of Mt. Apoi in Prov. Hidaka on Hokkaido. Later, Satake (1936) recognized $B$. paraspicata as a nomen nudum, and he 
Table 2. Comparison of the key morphological characters of the Boehmeria spicata complex.

\begin{tabular}{lcccc}
\hline \hline \multicolumn{1}{c}{ Character } & B. gracilis & B. paraspicata & B. silvestrii & B. spicata \\
\hline $\begin{array}{l}\text { Plant, habit } \\
\text { Stem, no. of branches }\end{array}$ & Subshrub & Subshrub & Subshrub & Small shrub \\
$\begin{array}{l}\text { Stipule, shape } \\
\text { Middle leaf blade }\end{array}$ & Lanceolate & A few & A few & Many \\
Shape & Lanceolate & Narrowly lanceolate & Narrowly lanceolate \\
& $\begin{array}{c}\text { Elliptic, broadly elliptic, ovate } \\
\text { or broadly depressed ovate }\end{array}$ & $\begin{array}{c}\text { Ovate to broadly } \\
\text { ovate }\end{array}$ & $\begin{array}{c}\text { 5-angled ovate, } \\
\text { orbicular ovate or } \\
\text { broadly ovate }\end{array}$ & Rhombic to rhombic \\
ovate
\end{tabular}

Bold letters indicate key character.

republished it with an accompanying Latin description and a specimen collected from Mt. Kanayama in Prov. Isikari on Hokkaido in August 1916 by G. Koidzumi (in TI herbarium). Among the examined specimens, there was a specimen that was assumed to have been collected when Nakai published $B$. paraspicata. Nakai's specimen and Koidzumi's specimen allowed confirmation that the characters of the habit, stem, leaf, and inflorescence are identical. Furthermore, in 1928, before the announcement of the new species, the specimen was annotated as 'B. paraspicata Nakai'. Moreover, the collection site and the collector were in good agreement with the protologue of Nakai (Fig. 1B). As a result, Satake (1936) knew that there was an original material of Nakai, but he recognized the specimen of Koidzumi collected earlier as the type specimen. However, the specimen of Nakai has priority because $B$. paraspicata is not a name based on the specimen of Koidzumi. Thus, B. paraspicata Nakai ex Satake, published based on the Koidzumi's specimen, is a later homonym of $B$. paraspicata Nakai according to Art. 53.1 of the Shenzhen code (Turland et al., 2018), and B. paraspicata Nakai was validly published according to Art. 38.1 of the Shenzhen code (Turland et al., 2018). Therefore, we present a holotype to avoid confusion regarding the type specimen (Fig. 1B).

This taxon is clearly distinguished from $B$. silvestrii by the unlobed apex of the leaf and from B. gracilis based on the broadly ovate shape of the middle leaf, the serrate-dentate margin of the leaf, the gradually larger teeth distal of the leaf, and the caudate or narrowly acute apex of the leaf (Figs. 3, 4, and Table 2).

3. Boehmeria silvestrii (Pamp.) W. T. Wang, Acta Phytotax. Sin. 20: 204, 1982; B. platanifolia (Franch. \& Sav. ex Maxim.) C. H. Wright var. silvestrii Pamp., Nuovo Giorn. Bot. Ital. n. s. 22: 278, 1915; B. japonica (L. f.) Miq. var. silvestrii (Pamp.) Friis \& Wilmot-Dear, Blumea. 58: 191, 2013.-TYPE: China. Hubei, 1912, P. C. Silvestri 4070 (lectotype: FI, photo!, designated here, see Fig. 1C), $4070 a$ (isolectotype: FI, photo!, designated here).

Korean name: Cham-geo-buk-kko-ri (참거북꼬리, new common name).

Habits subshrub, monoecious or dioecious. Stems erect, 0.8-1.4 $\mathrm{m}$ tall, 1.9-3.6 $\mathrm{mm}$ in diam., a few branched from the base, green or red, sparsely strigillose or subglabrous. Leaves opposite, pairs subequal in size; stipules narrowly lanceolate, 8.6-13.1 mm long, 1.7-3.2 mm wide, yellow green, sparsely pubescent along midvein on abaxial surface; petioles 4.3-13.2 $\mathrm{cm}$ long, $0.9-1.5 \mathrm{~mm}$ in diam., green or red, sparsely strigillose or subglabrous; middle leaf blades 5 -angled ovate, orbicular ovate or broadly ovate, $8.6-13.6 \mathrm{~cm}$ long, $8.1-13.1 \mathrm{~cm}$ wide, 


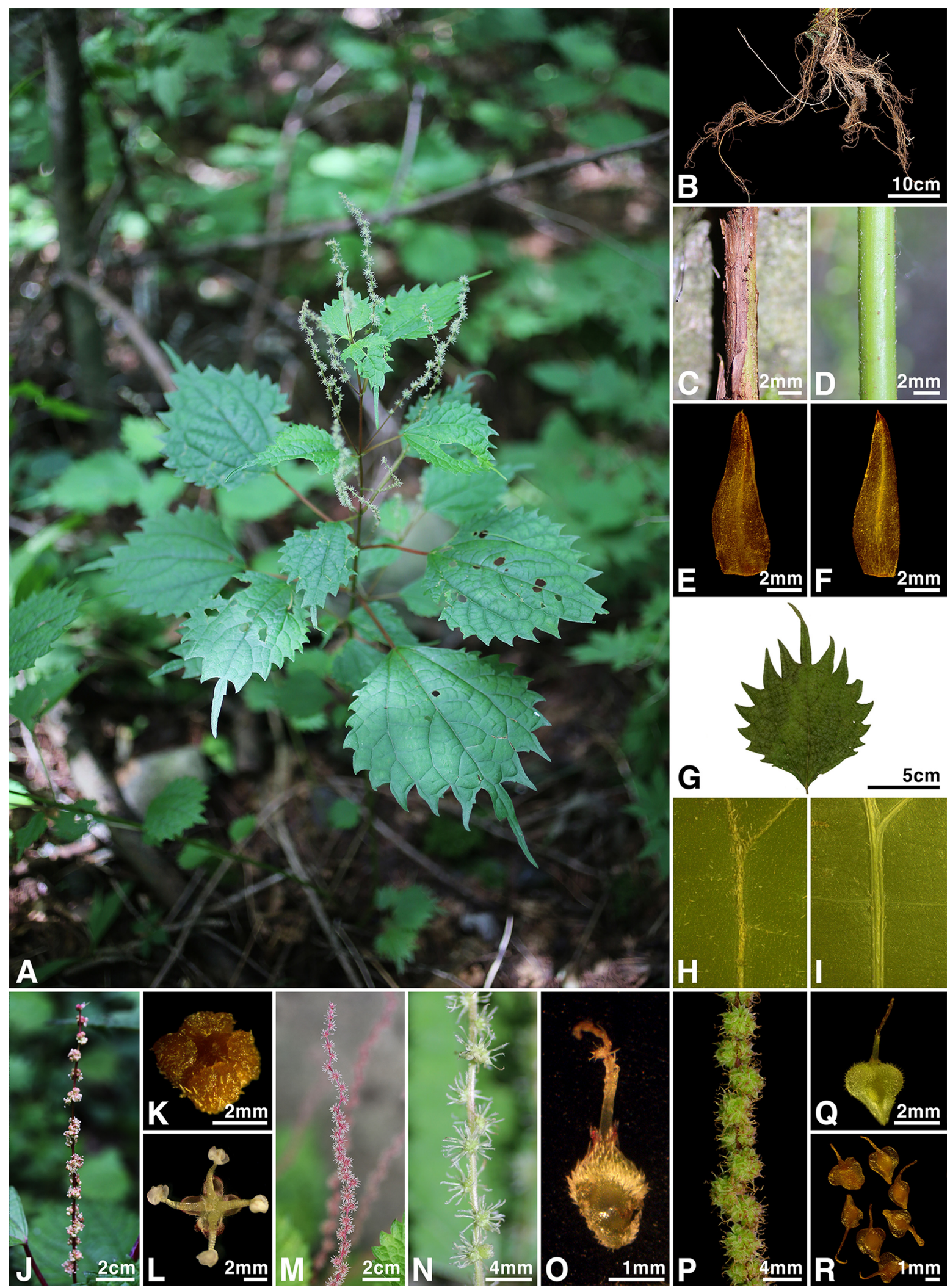

Fig. 4. Photographs of Boehmeria paraspicata. A. Habit. B. Underground structure. C. Base stem. D. Middle stem. E. Adaxial surface of stipule. F. Abaxial surface of stipule. G. Middle leaf. H. Adaxial surface of leaf. I. Abaxial surface of leaf. J. Staminate inflorescence. K. Bud of male flower. L. Male flower. M, N. Pistillate inflorescence at flowering. O. Female flower. P. Pistillate inflorescence at fruiting. Q. Achene. R. Seeds. 
base broadly cuneate or subtruncate, margin serrate-dentate, gradually larger distally, teeth $7-11$ on each side, narrowly triangular to triangular, 4.6-8.6 mm long, 6.4-10.5 mm wide, apex 3- or 5-caudate, adaxial surface green, sparsely strigillose or subglabrous, densely cystoliths punctiform, midvein convex, abaxial surface yellow green, sparsely strigillose with uncinate hair or subglabrous along veins and veinlets, often thin membranous or chartaceous. Inflorescences axillary; staminate inflorescences unbranched or rarely branched in proximal axils, 9.6-15.6 cm long, rachis $0.3-0.7 \mathrm{~mm}$ in diam.; pistillate inflorescences unbranched in distal axils, $11.2-22.2 \mathrm{~cm}$ long, rachis $0.3-0.5 \mathrm{~mm}$ in diam., loosely glomerules at flowering, relatively densely glomerules at fruiting. Flowers unisexual; male flowers 4-merous, $3.4-4.3 \mathrm{~mm}$ in diam.; pedicels 0.2 $1.1 \mathrm{~mm}$ long, green or red; perianth lobes cleft near to the middle, convex, elliptic, 0.8-1.0 mm long, 0.8-0.9 mm wide, yellow green or red, strigillose in outside; filaments 4 , linear, inflexed, $1.3-1.8 \mathrm{~mm}$ long, white; anthers basifixed, $0.6-0.9 \mathrm{~mm}$ long, 0.8--0.9 mm wide, white; ovaries rudimentary, clavate; female flowers 3.3-4.4 mm long, sessile; perianth tubes obovoid or rhomboid, $1.0-1.2 \mathrm{~mm}$ long, $0.7-1.5 \mathrm{~mm}$ wide, yellow green or red, strigillose with uncinate hair; necks 2-toothed; styles 1, linear, plumose, $0.9-1.5 \mathrm{~mm}$ long, white or red; stamens absent. Achenes rhomboid or obovoid, compressed, 3.1-4.5 mm long, 2.0-2.8 mm wide, base cuneate, irregular strigillose with uncinate hair throughout the surface. Seeds elliptic or subcircular, 0.8-1.1 mm long, $0.6-0.9 \mathrm{~mm}$ wide; wings obovoid or obdeltoid, 1.3-2.0 mm long, $0.8-1.3 \mathrm{~mm}$ wide.

Chromosome number: $2 n=42$ (Okabe, 1963).

Phenology: Flowering June to September, Fruiting September to November.

Distribution: Korea (all provinces except Jeju Island), China, Japan.

Taxonomic note: Boehmeria silvestrii and B. tricuspis are often misidentified and confused with each other because the apex of the leaf has a 3-lobed shape. Therefore, most studies in the literature confused these two with each other (Makino, 1940, 1961, 1989; Ohwi, 1953, 1965; Kitamura and Murata, 1961; Im, 1996; Lee, 1996a, 1996b; Lee, 2003; Tateishi, 2006; Liang, 2009; Wilmot-Dear and Friis, 2013; Kim, 2018). Boehmeria silvestrii is clearly distinguished from $B$. tricuspis as it is subshrubs with sparsely strigillose or subglabrous stems, sparsely strigillose leaves, a lobed perianth of the male flower, an unbranched pistillate inflorescence, and an irregular strigillose achene (Figs. 5, 6). It was newly named 'Cham-geobuk-kko-ri' to avoid confusion with $B$. tricuspis. This taxon has a 3- or 5-lobed leaf apex, unlike other taxa of the B. spicata complex (Figs. 3, 5, and Table 2).
4. Boehmeria spicata (Thunb.) Thunb., Trans. Linn. Soc. Lond. 2: 330, 1794; Urtica spicata Thunb., Syst. Veg., ed. 14, 850, 1784, pro part.; Duretia spicata (Thunb.) Nakai, Bull. Natl. Sci. Mus. Tokyo. 31: 42, 1952, nom. illeg.-TYPE: Japan. 1984, C. P. Thunberg 22115 (lectotype: UPS, photo!, designated by Yahara, J. Jap. Bot. 59: 130, 1984, see Fig. 1D).

B. spicata var. tenera Blume, Mus. Bot. 2: 220, 1857; B. japonica (L. f.) Miq. var. tenera (Blume) Friis \& Wilmot-Dear, Blumea. 58: 193, 2013.-TYPE: Japan. Unknown collector s.n., Lugd.-Bat. 908.186-164 (holotype: L).

B. spicata var. akari Blume, Mus. Bot. 2: 220, 1857.-TYPE: Japan. Unknown collector s.n., Lugd.-Bat. 908.186-156 (holotype: L).

B. spicata var. microphylla Nakai ex Satake, J. Fac. Sci. Univ. Tokyo, Sect. 3, Bot. 4: 483, 1936.-TYPE: Japan. Honshu, Prov. Izu, Mt. Amagi, 26 Jun 1931, T. Nakai s.n. (holotype: TI, photo!).

Korean name: Jom-kkae-ip-na-mu (좀깨잎나무).

Habits small shrub, monoecious or dioecious. Stems erect, 0.6-2.5 $\mathrm{m}$ tall, $1.2-3.0 \mathrm{~mm}$ in diam., many branched from the base, brown, often densely black pubescent, barks peeled off; branches green or red, sparsely strigillose or subglabrous. Leaves opposite, pairs subequal in size; stipules narrowly lanceolate, 3.9-7.0 mm long, 1.1-1.9 mm wide, yellow green, sparsely pubescent along midvein on abaxial surface; petioles $2.2-7.5 \mathrm{~cm}$ long, $0.5-1.0 \mathrm{~mm}$ in diam., green or red, sparsely strigillose; middle leaf blades rhombic to rhombic ovate, 5.7$10.5 \mathrm{~cm}$ long, 3.5-6.8 cm wide, base cuneate or sometimes broadly cuneate, margin serrate-dentate, gradually larger distally, teeth 4-9 on each side, narrowly triangular, 3.8-10.0 $\mathrm{mm}$ long, 4.9-10.5 mm wide, apex unlobed, caudate or narrowly acute, adaxial surface green, sparsely strigillose, densely cystoliths punctiform, midvein convex, abaxial surface yellow green, often sparsely strigillose with uncinate hair or subglabrous along veins and veinlets, often chartaceous. Inflorescences axillary; staminate inflorescences unbranched or rarely branched in proximal axils, 4.6-15.7 cm long, rachis $0.2-0.7 \mathrm{~mm}$ in diam.; pistillate inflorescences unbranched in distal axils, 7.7-21.4 cm long, rachis $0.3-0.5 \mathrm{~mm}$ in diam., loosely glomerules at flowering and fruiting. Flowers unisexual; male flowers 4-merous, 3.7-4.5 $\mathrm{mm}$ in diam.; pedicels $0.3-0.7 \mathrm{~mm}$ long, green or red; perianth lobes cleft near to the middle, convex, elliptic, $0.7-0.9 \mathrm{~mm}$ long, $1.0-1.1$ $\mathrm{mm}$ wide, yellow green or red, strigillose in outside; filaments 4, linear, inflexed, 1.6-1.9 mm long, white; anthers basifixed, $0.8-1.1 \mathrm{~mm}$ long, $0.8-1.0 \mathrm{~mm}$ wide, white; ovaries rudimentary, clavate; female flowers $3.4-5.1 \mathrm{~mm}$ long, sessile; perianth tubes 


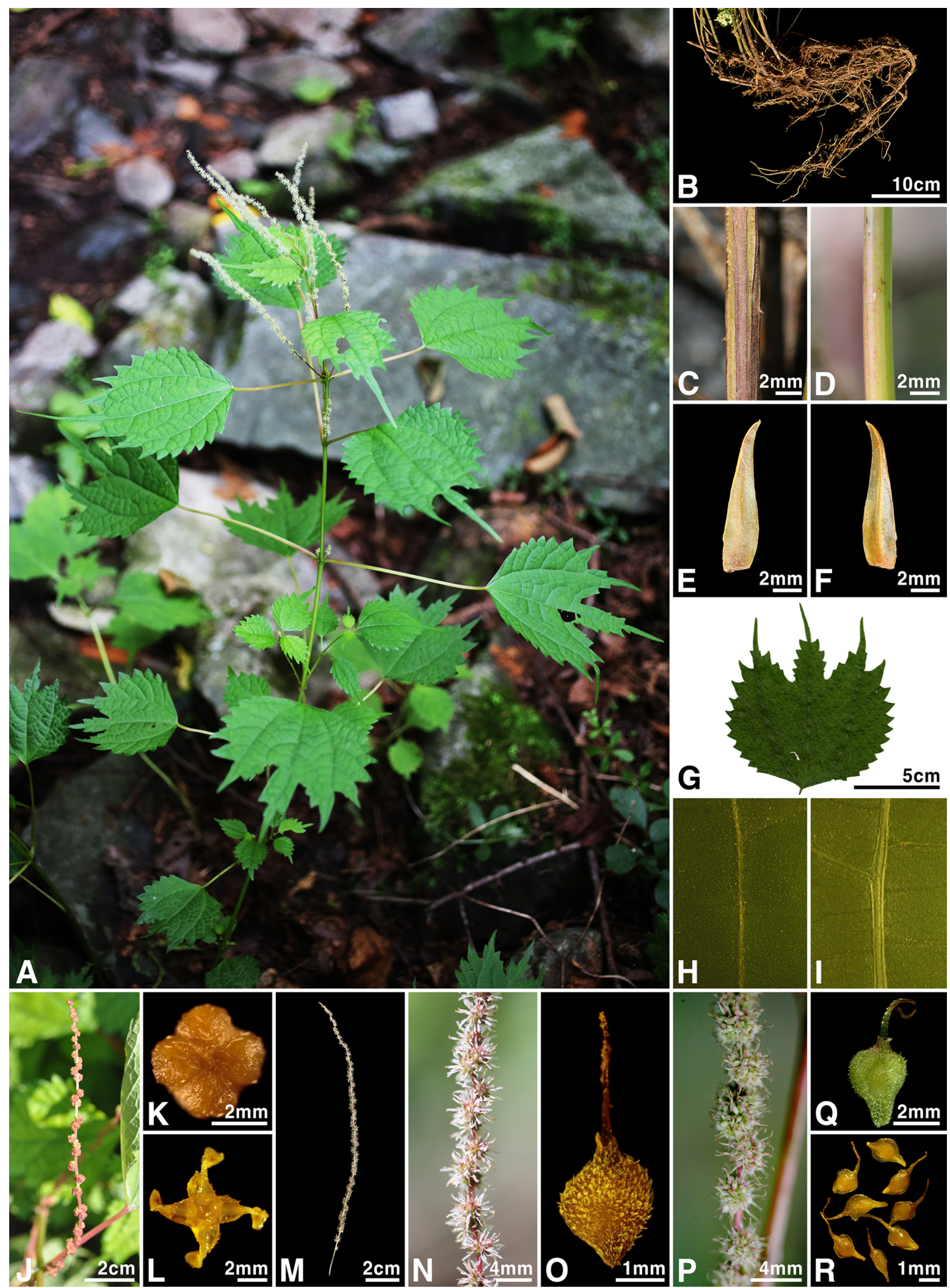

Fig. 5. Photographs of Boehmeria silvestrii. A. Habit. B. Underground structure. C. Base stem. D. Middle stem. E. Adaxial surface of stipule. F. Abaxial surface of stipule. G. Middle leaf. H. Adaxial surface of leaf. I. Abaxial surface of leaf. J. Staminate inflorescence. K. Bud of male flower. L. Male flower. M, N. Pistillate inflorescence at flowering. O. Female flower. P. Pistillate inflorescence at fruiting. Q. Achene. R. Seeds. 


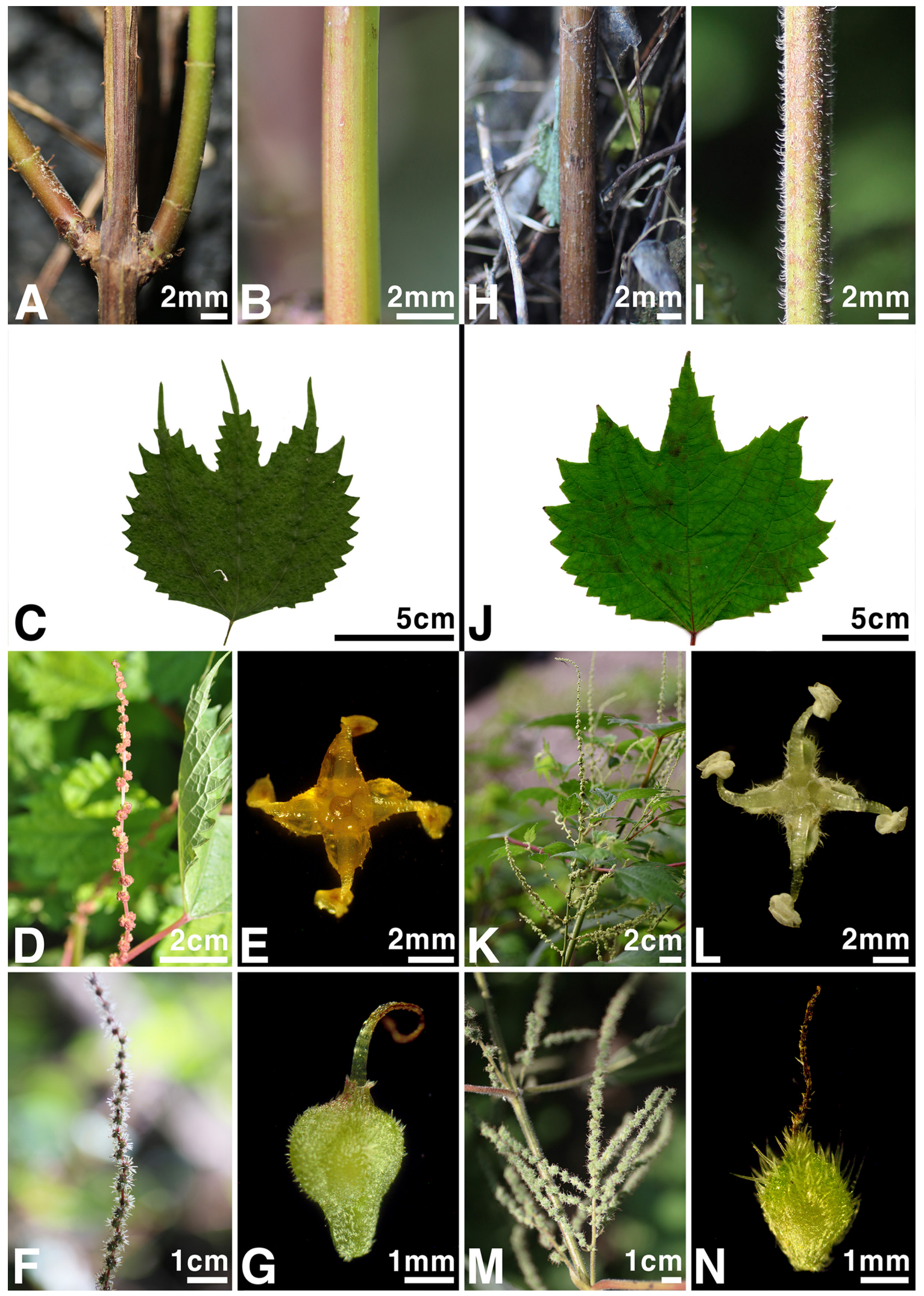

Fig. 6. Comparative photographs of Boehmeria silvestrii and B. tricuspis. A-G. B. silvestrii. H-N. B. tricuspis. A, H. Base stem. B, I. Middle stem. C, J. Middle leaf. D, K. Staminate inflorescence. E, L. Male flower. F, M. Pistillate inflorescence. G, N. Achene. 


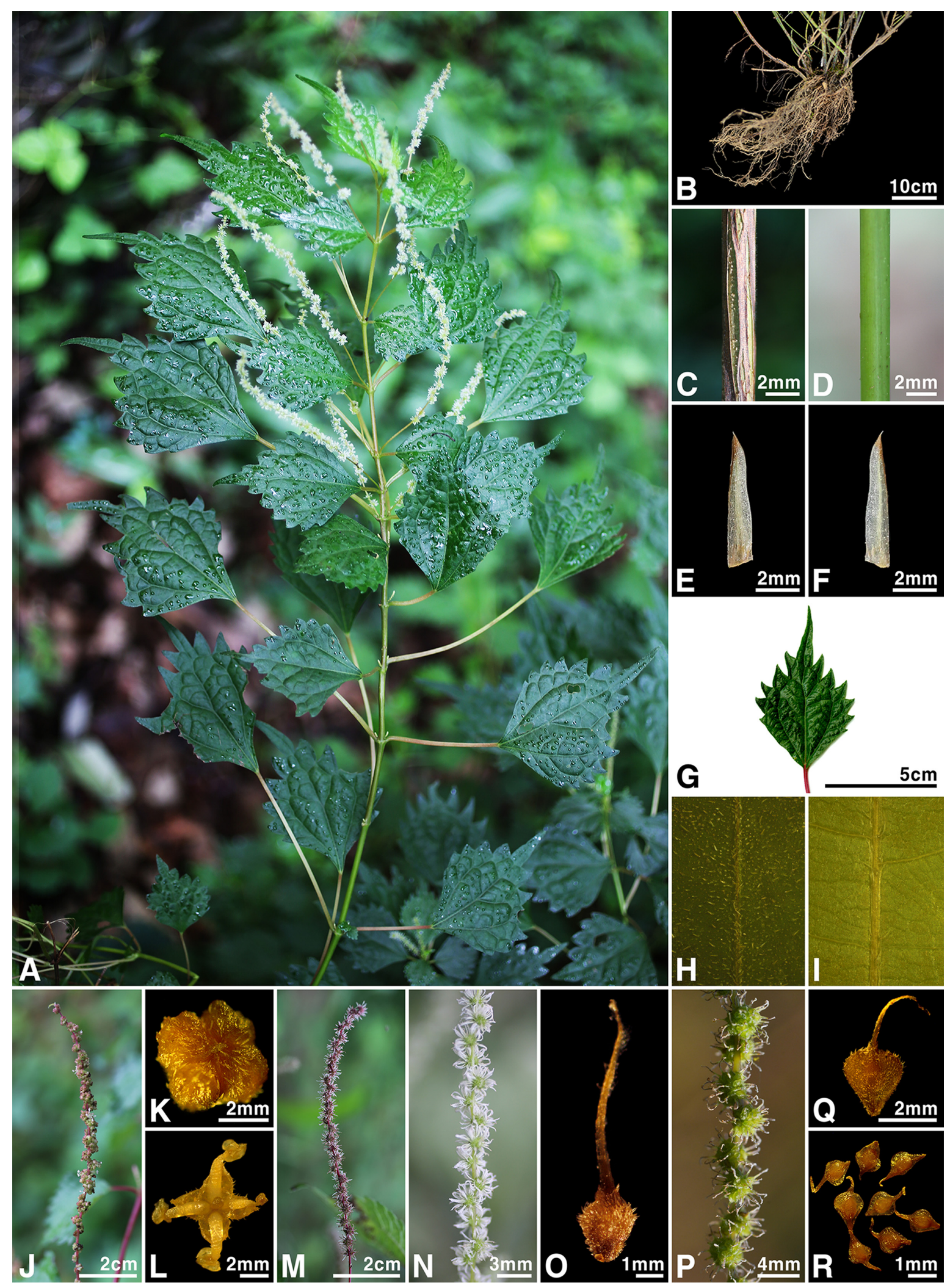

Fig. 7. Photographs of Boehmeria spicata. A. Habit. B. Underground structure. C. Base stem. D. Branch. E. Adaxial surface of stipule. F. Abaxial surface of stipule. G. Middle leaf. H. Adaxial surface of leaf. I. Abaxial surface of leaf. J. Staminate inflorescence. K. Bud of male flower. L. Male flower. M, N. Pistillate inflorescence at flowering. O. Female flower. P. Pistillate inflorescence at fruiting. Q. Achene. R. Seeds. 
obovoid, 1.1-2.1 mm long, 0.6-1.3 mm wide, yellow green or red, strigillose with uncinate hair; necks 2-toothed; styles 1, linear, plumose, 1.1-1.9 mm long, white or red; stamens absent. Achenes rhomboid or obovoid, compressed, 2.4-3.3 mm long, 2.0-2.6 mm wide, base cuneate, irregular strigillose with uncinate hair throughout the surface. Seeds elliptic or subcircular, 0.8-0.9 mm long, 0.5-0.6 mm wide; wings rhomboid-obovoid or broadly obovoid, $1.2-1.5 \mathrm{~mm}$ long, $0.9-1.2 \mathrm{~mm}$ wide.

Chromosome number: $2 n=28,42$ (Okabe, 1963; Yahara, 1983, 1984).

Phenology: Flowering July to September, Fruiting September to November.

Distribution: Korea (all provinces), China, Japan.

Taxonomic note: This taxon is distinguished from related taxa as it is a subshrub with many branching stems at the base, peeled bark, a densely black pubescent woody stem, and a rhombic to rhombic ovate middle leaf (Figs. 3, 7, and Table 2). In addition, it is often confused with B. paraspicata, but it is different in terms of the habit, leaf shape, and leaf size.

\section{Key to the Boehmeria spicata complex and the related taxa in Korea}

1. Habits subshrub or small shrub; plants sparsely strigillose or subglabrous; midvein of leaves convex on the adaxial surface; perianth of male flowers cleft; pistillate inflorescences unbranched; perianth tube of achenes irregular strigillose throughout the surface

2. Habits subshrub with woody stem only at base; woody stems glabrous; stems a few branched; middle leaf blades not rhombic to rhombic ovate

3. Leaf apexes unlobed

4. Middle leaf blades elliptic, broadly elliptic, ovate, or broadly depressed ovate, margin serrulate-dentate, teeth subequal distally, apex short caudate or cuspidate

4. Middle leaf blades ovate to broadly ovate, margin serrate-dentate, teeth gradually larger distally, apex caudate or narrowly acute ……... 2. B. paraspicata 풀거북꼬리

3. Leaf apexes 3- or 5-lobed

3. B. silvestrii 참거북꼬리

2. Habits small shrub with woody stem throughout; woody stems often densely black pubescent; stems many-branched; middle leaf blades rhombic to rhombic ovate …………... 4. B. spicata 좀깨잎나무 1. Habits perennial herb; plants densely pubescent or strigose; midvein of leaves compressed on the adaxial surface; perianth of male flowers parted; pistillate inflorescences usually branched; perianth tube of achenes strigose on apical part ……… 5. B. tricuspis 거북꼬리

ORCID: Hyeong Jun JO https://orcid.org/0000-0003-26220290; Jae Young KIM https://orcid.org/0000-0002-2327-8510; Yuri LEE https://orcid.org/0000-0003-1835-1020; Se Hee PARK https://orcid.org/0000-0001-7944-9502; Min Ji KWON https://orcid.org/0000-0002-8231-2037; Seon JEONG https:// orcid.org/0000-0002-8203-812X; Gyu Young CHUNG https:/ /orcid.org/0000-0002-4891-1140

\section{Acknowledgments}

This work was supported by a grant from the National Institute of Biological Resources (NIBR) funded by the Ministry of the Environment (MOE) of the Republic of Korea (NIBR202107101).

\section{Conflict of Interest}

The authors declare that there are no conflicts of interest.

\section{Literature Cited}

Blume, C. L. 1857. Museum Botanicum Lugduno-Batavum. Vol. 2, Brill, Leiden, 256 pp.

Chen, C. J., Q. Lin, I. Friis, C. M. Wilmot-Dear and A. K. Monro. 2003. Urticaceae Juss. In Flora of China, Vol. 5. Ulmaceae through Basellaceae. Wu, Z. Y. and P. H. Raven (eds.), Science Press, Beijing and Missouri Botanical Garden Press, St. Louis, MO. Pp. 76-189.

Forbes, F. B. and W. B. Hemsley. 1899. An enumeration of all the plants known from China Proper, Formosa, Hainan, Corea, the Luchu Archipelago, and the Island of Hongkong, together with their distribution and synonymy. Part XII. Botanical Journal of the Linnean Society 26: 457-538.

Gaudichaud, C. 1830. Botanique, part 12. In Voyage autour du monde,...exécuté sur les corvettes de S. M. l' Uranie et la Physiciene. Freycinet, H. D. (ed.), Pillet-Ainé, Paris. Pp. 465522.

Ilvessalo-Pfäffli, M. S. 1995. Fiber Atlas: Identification of Papermaking Fibers. Springer-Verlag, Berlin, 400 pp.

Im, R. J. 1996. Flora Coreana. Vol. 1. The Science and Technology Publishing House, Pyongyang. Pp. 260-268. (in Korean)

Jackson, B. D. 1895. Index Kewensis: An Enumeration of the Genera and Species of Flowering Plants. Vol. 1. Clarendon 
Press, Oxford, 1268 pp.

Kim, C. H. 2018. Boehmeria Jacq. In The Genera of Vascular Plants of Korea. Flora of Korea Editorial Committee (ed.), Hongrung Publishing Co., Seoul. Pp. 342-345.

Kitamura, S. and G. Murata. 1961. Coloured Illustrations of Herbaceous Plants of Japan. Vol. II (Choripetalae). Hoikusha Publishing Co., Osaka. Pp. 338-343. (in Japanese)

Kozłowski, R. M. 2012. Handbook of Natural Fibres: Volume 1: Types, Properties and Factors Affecting Breeding and Cultivation. Woodhead Publishing, Duxford. Pp. 47-49.

Lee, T. B. 2003. Coloured Flora of Korea. Vol. I. Hyangmunsa, Seoul. Pp. 236-239. (in Korean)

Lee, W. T. 1996a. Coloured Standard Illustrations of Korean Plants. Academy Publishing Co., Seoul. Pp. 66-67. (in Korean)

Lee, W. T. 1996b. Lineamenta Florae Koreae. Academy Publishing Co., Seoul. Pp. 196-200. (in Korean)

Lee, Y. N. 2006. New Flora of Korea, Vol. I. Kyohaksa, Seoul. Pp. 255-257. (in Korean)

Liang, S. A. 2009. A phylogenetic study of the genus Boehmeria in Korea. MS thesis, Yeungnam University, Gyeongsan, Korea, 90 pp.

Makino, T. 1940. An Illustrated Flora of Nippon, with the Cultivated and Naturalized Plants. Hokuryukan, Tokyo, 1070 pp. (in Japanese)

Makino, T. 1961. Boehmeria Jacq. In Makino's New Illustrated Flora of Japan. Maekawa, F., H. Hara and T. Tuyama (eds.), Hokuryukan Co., Ltd., Tokyo. Pp. 104-105. (in Japanese)

Makino, T. 1989. Boehmeria Jacq. In Revised Makino's New Illustrated Flora of Japan. Ono, M., H. Oba and M. Nishida (eds.), Hokuryukan Co., Ltd., Tokyo. Pp. 54-56. (in Japanese)

Nakai, T. 1930. Vegetation of Mt. Apoi in the Province of Hidaka, Hokkaido. Vol. 12. Ministry of Education, Science and Culture, Tokyo. Pp. 1-19. (in Japanese)

Ohwi, J. 1953. Flora of Japan. Shibundo, Tokyo. Pp. 440-443. (in Japanese)

Ohwi, J. 1965. Boehmeria Jacq. In Flora of Japan. Meyer, F. G. and E. H. Walker (eds.), Smithsonian Institution, Washington D.C. Pp. 390-392.

Okabe, S. 1963. Apomixis in the genus Boehmeria (cytological studies of the Apomixis in Angiosperms I). Science Reports of the Tohoku University 29: 207-215.

Pierozzi, N. I., R. M. Baroni and R. Benatti. 2008. Cytological investigations of the microsporogenesis in male-sterile ramie (Boehmeria nivea Gaud.) and its offspring. Cytologia 73: 2131.

Pinner, J. L. M. and T. A. Bence. 1987. Names of seed-bearing plants at the rank of family and below published between Jan- uary 1976 and the end of 1980 with some omissions from earlier years. In Index Kewensis, Suppl. 17. Davies, R. A. (ed.), Clarendon Press, Oxford. Pp. 1-356.

Satake, Y. 1936. Boehmeria japonica. Journal of the Faculty of Science, University of Tokyo 3: 467-542.

Tateishi, Y. 2006. Urticaceae. In Flora of Japan. Vol. II. Angiospermae, Dicotyledoneae, Archichlamydeae. Iwatsuki, K., D. E. Boufford and H. Ohba (eds.), Kodansha, Tokyo. Pp. 101108.

Turland, N. J., J. H. Wiersema, F. R. Barrie, W. Greuter, D. L. Hawksworth, P. S. Herendeen, S. Knapp, W. -H. Kusber, D.-Z. Li, K. Marhold, T. W. May, J. McNeill, A. M. Monro, J. Prado, M. J. Price and G. F. Smith. 2018. International Code of Nomenclature for Algae, Fungi, and Plants (Shenzhen Code) Adopted by the Nineteenth International Botanical Congress Shenzhen, China, July 2017. Regnum Vegetabile, Vol. 159. Koeltz Botanical Books, Glashütten, 253 pp.

Wang, W. T. 1981. Revisio Boehmeriae Sinicae. Acta Botanica Yunnanica 3: 307-328.

Wang, W. T. 2016. A revision of Boehmeria sect. Duretia ser. Spicatae (Urticaceae) of China. Bulletin of Botanical Research 36: $805-814$.

Weddell, H. A. 1856. Monographie de la famille des Urticacées. Nouvelles Archives du Muséum d'Histoire Naturelle, Paris 9: $1-591$.

Weddell, H. A. 1869. Urticacées. In Prodromus Systematis Naturalis Regni Vegetabilis, Vol. 16. Candolle, A. D. (ed.), Victoris Masson et Filii, Paris. Pp. 32-235.

Wilmot-Dear, C. M. and I. Friis. 1996. The New World species of Boehmeria and Pouzolzia (Urticaceae, tribus Boehmerieae): A taxonomic revision. Opera Botanica 129: 1-103.

Wilmot-Dear, C. M. and I. Friis. 2013. The Old World species of Boehmeria (Urticaceae, tribus Boehmerieae): A taxonomic revision. Blumea 58: 85-216.

Yahara, T. 1981. Taxonomic studies of the Urticaceae 1. The genus Boehmeria in Thailand. Acta Phytotaxonomica et Geobotanica 32: 1-21.

Yahara, T. 1983. A biosystematic study of the local populations of some species of the genus Boehmeria with special reference to apomixis. Journal of the Faculty of Science, University of Tokyo Section III Botany 13: 217-261.

Yahara, T. 1984. Note on the nomenclature and infraspecific classification of Boehmeria japonica (L. f.) Miq. and B. spicata (Thunb.) Thunb. (Urticaceae). The Journal of Japanese Botany 59: 129-142.

Yahara, T. 1986. Distribution of sexual and agamospermous populations of Boehmeria sylvestrii and its three relatives (Urticaceae). Memoirs of the National Science Museum, Tokyo 19: 
$121-132$.

Zhao, L. N., G. G. Zang, J. Cheng and Y. J. Li. 2003. The sex phe- notype and evolution in Boehmeria Jacq. Plant Fiber and Products 25: 209-212.

Appendix 1. Specimens examined for the Boehmeria spicata complex in this study.

1. Boehmeria gracilis. CHINA. Guizhou: Jiangkou Xian, Heiwan River, 27 Aug 1986, W. T. Wang \& C. J. Chen 557 (TI).

JAPAN. Honshu: Kanagawa Pref., Sagami, Bijosani, 1931, K. Hisauchi s.n. (TI); Nagano Pref., Koshibu-yu, 4 Aug 1966, M. Furuse 44326 (TI); Nagano Pref., Minamisaku-gun, 11 Aug 1978, J. Murata \& H. Ohba 5196 (TI); Nagano Pref., Minamisaku-gun, Mt. Sekibutsu, 11 Aug 1978, J. Murata \& H. Ohba 5263 (TI); ?, 29 Jul 1939, ? s.n. (TI); ?, 30 Aug 1935, ? s.n. (TI).

KOREA. Chungcheongbuk-do: Danyang-gun, Sobaeksan Mt., ? KOSPVP0000178316 (KB); Danyang-gun, Sobaeksan Mt., Cheondong Rest Area, 26 Jun 2020, H. J. Jo et al. HJ200626-002 (ANH); Jecheon-si, Deokdong Valley, 29 Aug 2019, H. J. Jo et al. HJ190829-005 (ANH); Chungcheongnam-do: Cheonan-si, Gwangdeoksan Mt., 12 Sep 2016, H. J. Jo et al. HJ160912-001 (ANH). Gangwon-do: Inje-gun, Bangtaesan Mt., 24 Aug 2010, J. S. Kim NIBRVP0000271703 (KB); Geumgangsan Mt., 14 Aug 1902, T. Uchiyama 481 (TI); Geumgangsan Mt., 14 Aug 1902, T. Uchiyama s.n. (TI); Odaesan Mt., 23 Jul 1958, ? 2727 (KH); Seoraksan Mt., 15 Jul 1959, J. S. Lee 2774 (KH); Oegeum River, 15 Jul 1936, T. Nakai 17052 (TI); Pyeongchang-gun, Cheongtaesan Mt., 8 Jul 2016, H. J. Jo et al. HJ160708-001 (ANH); Taebaek-si, Hyeol-dong, Hambaeksan Mt., 9 Sep 2016, H. J. Jo et al. HJ160909-002 (ANH); Taebaek-si, Hyeol-dong, Hambaeksan Mt., 26 Jun 2016, H. J. Jo et al. HJ160626-002, 003 (ANH); Wonju-si, Chiaksa Mt., 31 Jul 2009, C. H. Kim et al. KOSPVP0000177241 (KB). Gyeonggi-do: Gapyeong-gun, Hwaaksan Mt., 2 Aug 2016, H. J. Jo et al. HJ160802-007-012 (ANH); Gapyeong-gun, Hwaaksan Mt., 7 Sep 2016, H. J. Jo et al. HJ160907001-005, 008, 009 (ANH); Gapyeong-gun, Hwaaksan Mt., 28 Sep 2016, H. J. Jo et al. HJ160928-004 (ANH); Hanam-si, Geomdansan Mt., 23 Jul 2015, Y. Kwon \& J. M. Seol KOSPVP0000351542 (KB); Namyangju-si, Gwangneung, 29 Jul 1963, C. H. Lee 2699 (KH); Namyangju-si, Paldang, 29 Aug 1966, Y. H. Cho 2765 (KH); Yangpyeong-gun, Geumwangsan Mt., 9 Sep 2005, K. T. Yeo \& K. Heo 4440 (KB); Yangpyeonggun, Jungwonsan Mt., 31 Jul 2020, H. J. Jo et al. HJ200731-001 (ANH); Yeoncheon-gun, Godaesan Mt., 23 Aug 2000, K. C. Yang \& J. D. Jung EN2000AJOU80 (KB). Gyeongsangbuk-do: Bonghwa-gun, Baebawisan Mt., 22 Jul 2019, H. J. Jo et al. HJ190722-003 (ANH); Bonghwagun, Biryongsan Mt., 17 Jul 2019, H. J. Jo et al. HJ190717-001 (ANH); Bonghwa-gun, Cheongnyangsan Mt., 17 Aug 2016, H. J. Jo et al. HJ160817-004 (ANH); Bonghwa-gun, Mirimsan Mt., 12 Sep 2018, H. J. Jo et al. HJ180912-001 (ANH); Cheongsong-gun, Cheongsongeoreum Valley, 18 Jul 2016, H. J. Jo et al. HJ160718-003 (ANH); Gimcheon-si, Samdobong Mt., 21 Aug 2019, H. J. Jo et al. HJ190821-005 (ANH); Yeongcheon-si, Bohyeonsan Mt., 9 Jul 2019, H. J. Jo et al. HJ190709-001, 002 (ANH); Yeongyang-gun, Irwolsan Mt., 23 Jul 2016, H. J. Jo et al. HJ160723-001-003 (ANH); Yeongyang-gun, Irwolsan Mt., 26 Sep 2017, H. J. Jo et al. HJ170926-003 (ANH); Yeongyang-gun, Ulyeonsan Mt., 18 Aug 2002, G. Y. Chung et al. ANH020818-001 (ANH). Gyeongsangnam-do: Hapcheon-gun, Gaya-myeon, Gayasan Mt., 1983, Y. M. Kim \& S. K. Kim KNKA200005123029 (KH); Sancheong-gun, Jirisan Mt., 25 Aug 2009, H. I. Chun et al. KOSPVP0000177403 (KB). Hamgyungbukdo: Bolsang-gun, Sansa-myeon, 1 Aug 1939, T. Nakai s.n. (TI). Jeollabuk-do: Jangsu-gun, Jangansan Mt., Deoksan Valley, 17 Aug 2016, H. J. Jo et al. HJ160817-002 (ANH); Jinan-gun, Unjangsan Mt., 9 Sep 2017, H. J. Jo et al. HJ170909-001-003, 005 (ANH); Muju-gun, Deokyusan Mt., 4 Aug 1974, J. S. Chang 2711 (KH); Sunchang-gun, Gangcheonsan Mt., 8 Jul 2019, H. J. Jo et al. HJ190708-001 (ANH); Sunchang-gun, Hoemunsan Mt., 6 Aug 2019, H. J. Jo et al. HJ190806-007 (ANH). Seoul-si: Bukhansan Mt., 9 Jun 1963, C. Y. Lee 2715 (KH). Ulsan-si: Uljugun, Sangbuk-myeon, Baegunsan Mt., 11 Sep 2016, H. J. Jo et al. HJ160911-001 (ANH). ?: Namsan Mt., 1909, N. Okada s.n. (TI); ?: Namsandong, 11 Oct 1900, T. Uchiyama s.n. (TI); ?, 11 Aug 1924, T. Nakai 14896 (TI); ?, 14 Aug 1916, T. Nakai 5366 (TI).

2. Boehmeria paraspicata. CHINA. Sichuan: Dujianyan Municipality, Qinglongzui, 9 Sep 1988, D. E. Boufford \& B. Bartholomew 24749 (TI). JAPAN. Hokkaido: Hidaka, Mt. Apoi, Aug 1928, T. Nakai s.n. (TI). Honshu: Saitana Pref., Mt. Nitagoyama, 16 Aug 1986, J. Murata et al. 21531 (KH); Shizuoka Pref., Gotemba city, Mt. Ashitaka, 6-7 Oct 1982, T. Yahara \& T. Kubo 6483 (TI); Shizuoka Pref., Iwata-gun, Misajubocho,Tochuh, 10 Aug 1977, Y. Quadota 4417 (TI); Tochigi Pref., Nikko-shi, Hanaishi-machi, 6 Sep 1983, J. Murata and T. Yahara 16111 (KH); Tokyo Pref., Oume-shi, Nagafuchi, 29 Sep 1986, H. T. Im \& T. Kawahara 7882 (KH); ?, 23 Aug 1993, H. Masaki s.n. (TI).

KOREA. Chungcheongbuk-do: Danyang-gun, Sobaeksan Mt., 19 Aug 2011, B. U. Oh et al. 25360 (KH); Danyang-gun, Sobaeksan Mt., Cheondong Rest Area, 26 Jun 2020, H. J. Jo et al. HJ200626-004 (ANH); Danyang-gun, Sobaeksan Mt., Eouigok, 26 Jun 2020, H. J. Jo et al. HJ200626-003 (ANH); Danyang-gun, Yongsanbong Mt., 11 Aug 2012, J. S. An et al. PTFLVP0000263469 (KB); Jecheon-si, Deokdong Valley, 29 Aug 2019, H. J. Jo et al. HJ190829-004 (ANH); Jecheon-si, Hansu-myeon, 29 Aug 2019, H. J. Jo et al. HJ190829-001-003 (ANH); Jecheonsi, Hansu-myeon, 7 Jul 2020, H. J. Jo et al. HJ200707-001 (ANH); Jecheon-si, Baegunsan Mt., 10 Jul 2011, B. U. Oh et al. 25359 (KH); Okcheon-gun, Annae-myeon, 28 Aug 2019, H. J. Jo et al. HJ190828-001 (ANH). Chungcheongnam-do: Cheongyang-gun, Chilgapsan Mt., Naengcheon Valley, 9 Jun 2016, H. J. Jo et al. HJ160609-004 (ANH). Daegu-si: Dalseong-gun, Choejeongsan Mt., 4 Oct 2019, H. J. Jo et al. HJ191004-002 (ANH). Gangwon-do: Chuncheon-si, Geombongsan Mt., 28 Jul 2006, H. K. Choi \& H. R. Na VP-KB-377033-0016 (KB); Gangneung-si, Daegwallyeong road, 28 Jul 2002, E. S. Jeon \& G. H. Nam L-60584 (KH); Goseong-gun, Myeongho-ri, 4 Aug 1987, W. T. Lee 2436 (KH); Inje-gun, Bangtaesan Mt., 9 Aug 2018, H. J. Jo et al. HJ180809-001 (ANH); Inje-gun, Bangtaesan Mt., 25 Aug 2018, H. J. Jo et al. HJ180825-001, 004, 005 (ANH); Inje-gun, Seoraksan Mt., 20 Jun 2016, H. J. Jo et al. HJ160620-001 (ANH); Jeongseon-gun, Gariwangsan Mt., 21 Jun 2016, H. J. Jo et al. HJ160621-002, 003 (ANH); Jeongseon-gun, Gariwangsan Mt., Janggumogi Valley, 23 Jun 2016, H. J. Jo et al. HJ160623-002 (ANH); Jeongseon-gun, Gariwangsan Mt., Janggumogi Valley, 12 Aug 2016, H. J. Jo et al. HJ160812-003-005 (ANH); Jeongseongun, Sindong-eup, Unchi-ri, 5 Aug 2016, H. J. Jo et al. HJ160805-001 (ANH); Jeongseon-gun, Yeoryang-myeon, Gujeol-ri, 8 Jul 2020 , H. J. Jo et al. HJ200708-002 (ANH); Pyeongchang-gun, Dong River, 16 Aug 2013, H. I. Chun et al. KOSPVP0000299884 (KB); Samcheok-si, Dutasan 
Mt., ?, H. R. Na et al. s.n. (KB); Taebaek-si, Hyeol-dong, Hambaeksan Mt., 26 Jun 2016, H. J. Jo et al. HJ160626-004-008 (ANH); Taebaeksi, Hyeol-dong. Mt. Hambaek, 20 Aug 2016, H. J. Jo et al. HJ160820-005-007 (ANH); Taebaek-si, Hyeol-dong, Hambaeksan Mt., 9 Sep 2016, H. J. Jo et al. HJ160909-003, 004 (ANH); Yeongwol-gun, Sangdong, 13 Aug 1959, Y. J. Kim 2752 (KH); Yeongwol-gun, Eungbongsan Mt., 22 Jun 2013, M. K. Lee et al. NIBRVP0000554020 (KB). Gyeonggi-do: Gapyeong-gun, 18 Jul 1981, S. C. Ko \& B. U. Oh CJUA200004291012 (KH); Gapyeong-gun, Hwaaksan Mt., 7 Sep 2016, H. J. Jo et al. HJ160907-010, 011 (ANH); Gapyeong-gun, Hwaaksan Mt., 28 Sep 2016, H. J. Jo et al. HJ160928-001-003 (ANH); Namyangju-si, Gwangneung, 16 Jul 1982, N. S. Lee et al. 57 (KH); Namyangju-si, Gwangneung, 28 Jul 1960, Y. J. Kim 2780 (KH); Pocheon-si, Jugyeopsan Mt., 20 Aug 2011, K. H. Kim KOSPVP0000240747 (KB). Gyeongsangbuk-do: Andong-si, Mt. Galla, 9 Aug 2016, H. J. Jo et al. HJ160809-002 (ANH); Andong-si, Gallasan Mt., 9 Aug 2016, H. J. Jo et al. HJ160809-003-007 (ANH); Andong-si, Seohu-myeon, Bongjeong Temple, 25 Jun 2018, H. J. Jo et al. HJ180625-001 (ANH); Bonghwa-gun, Mallisan Mt., 14 Sep 2018 , H. J. Jo et al. HJ180914-001 (ANH); Bonghwa-gun, Seondalsan Mt., 27 Sep 2018, H. J. Jo et al. HJ180927-001-003 (ANH); Bonghwa-gun, Sangun-myeon, Bibongsan Mt., 19 Jun 2020, H. J. Jo et al. HJ200619-002 (ANH); Chilgok-gun, Gasansanseong, 25 Sep 2019, H. J. Jo et al. HJ190925-001 (ANH); Chilgok-gun, Palgongsan Mt., 21 Aug 2012, W. J. Lee NIBRVP0000567816 (KB); Gimcheon-si, Samdobong Mt., 21 Aug 2019, H. J. Jo et al. HJ190821-001-003 (ANH); Mungyeong-si, Baekwasan Mt., 12 Jul 2019, H. J. Jo et al. HJ190712-001, 002 , 004 (ANH); Mungyeong-si, Joryeongsan Mt., 3 Jun 2016, H. J. Jo et al. HJ160603-001 (ANH); Uiseong-gun, Uiseong-eup, Oro-ri, 1 Jul 2016, W. J. Lee NIBRVP0000587627 (KB); Ulleung-gun, Gitdaebong Mt., 30 Jul 2019, H. J. Jo et al. HJ190730-006 (ANH); Ulleung-gun, Seonginbong Mt., 17 Jun 2016, H. J. Jo et al. HJ160617-004, 005, 007 (ANH); Ulleung-gun, Naribunji, 17 Oct 2016, H. J. Jo et al. HJ161017-003 (ANH); Ulleung-gun, Naribunji, 30 Jul 2019, H. J. Jo et al. HJ190730-007 (ANH); Yeongcheon-si, Hwabuk-mteon, Bohyeonsan Mt., 4 Jun 1998, J. H. Park et al. 5003 (KH); Yeongcheon-si, Giryongsan Mt., 16 Jul 2015, H. J. Lee \& J. D. Jeon KOSPVP0000349925 (KB); Yeongcheon-si, Sinnyeong-myeon, Palgongsan Mt., Birobong, 3 Jun 2020, H. J. Jo et al. HJ200603-001 (ANH); Yeongju-si, Sobaeksan Mt., 7 Jul 2011, B. U. Oh et al. 25356 (KH); Yeongju-si, Sobaeksan Mt., Choam Temple, 24 Oct 2018, H. J. Jo et al. HJ181024-001 (ANH); Yeongju-si, Sobaeksan Mt., Huibang Temple, 7 Jul 2020, H. J. Jo et al. HJ200707-002, 003 (ANH); Yeongyang-gun, Cheonggi-myeon, Cheonggi Lake, 12 Jun 2020 , H. J. Jo et al. HJ200612-002 (ANH); Yeongyang-gun, Cheonggi-myeon, Cheonggi Lake, 9 Jul 2020, H. J. Jo et al. HJ200709-001, 002 (ANH); Yeongyang-gun, Irwolsan Mt., 23 Jul 2016, H. J. Jo et al. HJ160723-004 (ANH); Yeongyang-gun, Irwolsan Mt., 15 Aug 2016, H. J. Jo et al. HJ160815-001 (ANH); Yeongyang-gun, Irwolsan Mt., 26 Sep 2017, H. J. Jo et al. HJ170926-001, 002 (ANH); Yeongyang-gun, Irwolsan Mt., Iljabong, 13 Aug 2019, H. J. Jo et al. HJ190813-001-003 (ANH). Gyeongsangnam-do: Hapcheon-gun, Gayasan Mt., 28 Jul 2016, H. J. Jo et al. HJ160728-004 (ANH). Jeju-do: Jeju-si, Aewol-eup, Musucheon, 27 Jul 2016, H. J. Jo et al. HJ160727-004 (ANH); Jeju-si, Aewol-eup, Musucheon, 27 Jul 2016, H. J. Jo et al. HJ160727-005 (ANH); Seogwipo-si, Sillye-ri, 10 Oct 2011, G. R. Kim et al. 10017314 (WFRC). Jeollabukdo: Jinan-gun, Bugwisan Mt., 31 Jul 2005, H. J. Choi CHJ50310 (KH); Jinan-gun, Unjangsan Mt., 17 Jul 2016, H. J. Jo et al. HJ160717-006, 007 (ANH); Muju-gun, Deokyusan Mt., 5 Oct ?, S. H. Kim et al. s.n. (KB); Sunchang-gun, Hoemunsan Mt., 6 Aug 2019, H. J. Jo et al. HJ190806-006 (ANH). Jeollanam-do: Damyang-gun, Wolsan-myeon, Yongheung-sa, 19 Oct 2001, H. T. Im 12212 (KH). Seoul-si: Namsan Mt., 16 Jul 1902, T. Uchiyama s.n. (TI).

3. Boehmeria silvestrii. CHINA. Shaanxi: Liba country, Zibai Forest Park, 28 Aug 2008, C.-S. Chang et al. KHB1205879 (KH); Liba country, Zibai Forest Park, 28 Aug 2008, C.-S. Chang et al. KHB1205880 (KH); Xian city, Hu-xian, ZhuQue Forest Park, 2 Jul 2008, J. L. Jeon et al. KHB1205255, KHB1205256 (KH). ?, 29 Jul 1929, M. Kitagawa s.n. (TI).

JAPAN. Honshu: Fukui Pref., Nojiri, Ikesa-cho, Imadate-gun, 2 Aug 1998, N. Kurosaki 21106 (TI); Fukushima Pref., Yama-gun, Yamatomachi, Ichinoki, 28 Aug 1980, H. Ohba \& S. Akiyama s.n. (TI); Kouchi Pref., Takaoka District, Ohnomi village, Shimano-kawa, 13 Aug 2005 , T. Miyazaki 508223 (TI); Mie Pref., Aoyamatouge, 24 Jun 1932, Y. Maekawa 4940 (TI); Shizuoka Pref., Gotemba City, Ashitaka Mt., 6-7 Oct 1982, T. Yahara \& T. Kubo 6461 (TI). Shikoku: Kochi Pref., Agawa village, Nakatu Mt., 13 Aug 2003, T. Miyazaki 308016 (TI).

KOREA. Chungcheongbuk-do: Danyang-gun, Sobaeksan Mt., 17 Jul 1999, C. W. Park et al. 10606 (KH); Danyang-gun, Sobaeksan Mt., Cheondong, 26 Jun 2020, H. J. Jo et al. HJ200626-001 (ANH); Eumseong-gun, Sureuisan Mt., 21 Jun 2015, J. S. Yoo \& H. T. Kim KOSPVP0000349500 (KB); Yeongdong-gun, Minjujisan Mt., 12 Aug 2014, J. H. Park NIBRVP00005627 (KB). Daegu-si: Dalseong-gun, Choejeongsan Mt., 4 Oct 2019, H. J. Jo et al. HJ191004-001 (ANH). Gangwon-do: Cheorwon-gun, Naebongsan Mt., 12 Jul 1993, S. T. Lee et al. 51155 (KH); Chuncheon-si, Dong-myeon, Gamjeong-ri, 2 Jul 2011, S. H. Cho 38 (KH); Gangneung-si, Baegunsan Mt., 29 Jun 1996, W. T. Lee 2442 (KH); Goseong-gun, Mt. Hyangnobong, 29 Jul 2010, K. O. Yoo 77160 (KH); Hongcheon-gun, Eungboksan Mt., 28 Jul 1987, W. T. Lee 2435 (KH); Hwacheon-gun, Samil-ri, Hwaaksan Mt., 12 Aug 2006, S. H. Kim et al. 2006-0843 (KH); Inje-gun, Girin-myeon, Bangtaesan Mt., 25 Sep 2011, S. H. Cho et al. HHU2012-0579 (KH); Inje-gun, Bangtaesan Mt., 9 Aug 2018, H. J. Jo et al. HJ180809-002, 003 (ANH); Jeongseon-gun, Deoksangi Valley, 15 Sep 2014, J. H. Kim et al. NIBRVP0000484237 (KB); Jeongseon-gun, Jeongseon-eup, Gariwangsan Mt., 28 Jun 2011, C. H. Lee et al. L110234 (KH); Jeongseon-gun, Duwibong Mt., 11 Jul 2015, M. G. Lee \& M. J. Jung NIBRVP00005765 (KB); Jeongseon-gun, Gariwangsan Mt., Janggumogi Valley, 23 Jun 2016, H. J. Jo et al. HJ160623-001 (ANH); Jeongseon-gun, Gariwangsan Mt., Janggumogi Valley, 12 Aug 2016, H. J. Jo et al. HJ160812-001, 002, 008 (ANH); Jeongseon-gun, Yeoryang-myeon, Gujeol-ri, 8 Jul $2020, H$. J. Jo et al. HJ200708-001 (ANH); Pyeongchang-gun, Cheongoksan Mt., 23 Jul 2016, Y. S. Oh \& E. A. Kim NIBRVP0000599384 (KB); Pyeongchang-gun, Odaesan Mt., 18 Jul 1998, H. K. Wu 497 (KH); Samcheok-si, Dutasan Mt., 23 Aug 1996, W. T. Lee 2440 (KH); Samcheoksi, Eungbongsan Mt., 2 Oct 2008, K. O. Yoo 69486 (KH); Taebaek-si, Hyeol-dong, Taebaeksan Mt., 26 Jun 2016, H. J. Jo et al. HJ160626-001 (ANH); Taebaek-si, Hyeol-dong, Taebaeksan Mt., 27 Jun 2013, S. H. Park et al. P131637 (KH); Taebaek-si, Hyeol-dong, Hambaeksan Mt., 20 Aug 2016, H. J. Jo et al. HJ160820-001 (ANH); Taebaek-si, Hyeol-dong, Hambaeksan Mt., 9 Sep 2016, H. J. Jo et al. HJ160909-001 (ANH); Taebaek-si, Hambaeksan Mt., 5 Jul 2014, B. K. Park KOSPVP0000309701 (KB). Gyeonggi-do: Gapyeong-gun, Hwaaksan Mt., 2 Aug 2016, H. 
J. Jo et al. HJ160802-001-006 (ANH); Gapyeong-gun, Hwaaksan Mt., 7 Sep 2016, H. J. Jo et al. HJ160907-006, 007 (ANH); Gapyeong-gun, Hwaaksan Mt., 28 Sep 2016, H. J. Jo et al. HJ160928-005-009 (ANH); Gapyeong-gun, Myeongjisan Mt., 6 Jun, 2001, C. H. Kim JNU7707 (KH); Yangpyeong-gun, Aeongjabong Mt., 30 Jun 1985, E. J. Lee 3141013 (KH); Yongin-si, Gogi-dong, Gwanggyosan Mt., 8 Oct 2007 , H. J. Kim et al. 53643 (KH). Gyeongsangbuk-do: Bonghwa-gun, Baebawisan Mt., 22 Jul 2019, H. J. Jo et al. HJ190722-002 (ANH); Bonghwa-gun, Biryongsan Mt., 17 Jul 2019, H. J. Jo et al. HJ190717-002, 003 (ANH); Bonghwa-gun, Cheongnyangsan Mt., 16 Sep 2019, H. J. Jo et al. HJ190916-001 (ANH); Bonghwa-gun, Sangun-myeon, Bibongsan Mt., 19 Jun 2020, H. J. Jo et al. HJ200619-001 (ANH); Bonghwa-gun, Socheonmyeon, Biryongsan Mt., Biryong Falls, 3 Jun 2019, H. J. Jo et al. HJ190603-001, 002 (ANH); Gimcheon-si, Samdobong Mt., 21 Aug 2019 , H. J. Jo et al. HJ190821-006 (ANH); Gimcheon-si, Sudosan Mt., 14 Jun 2014, J. W. Jeong NIBRVP0000588515 (KB); Uljin-gun, Deogu-ri, Jangjaesan Mt., 21 Jul 1995, S. W. Hong \& E. K. Kwak 57 (KH); Ulleung-gun, Buk-myeon, Nari-ri, Naribunji, 15 Jul 2008, G. Y. Chung et al. ANH0000943 (KH); Ulleung-gun, Dodong-ri, Seonginbong Mt., 30 Jul 2019, H. J. Jo et al. HJ190730-005 (ANH); Ulleung-gun, Seonginbong Mt., 17 Jun 2016, H. J. Jo et al. HJ160617-001 (ANH); Ulleung-gun, Naribunji, 17 Oct 2016, H. J. Jo et al. HJ161017-004-006 (ANH); Ulleung-gun, Naribunji, 14 Jul 2005, M. H. Lee et al. 2005-2414 (KH); Ulleung-gun, Ulleung-eup, Dodong-ri, 23 Apr 2009, G. Y. Chung et al. ANH00009809 (KH); Ulleung-gun, Ulleung-eup, Dodong-ri, Bongnae Falls, 18 Oct 2016, H. J. Jo et al. HJ161018-005 (ANH); Yeongcheon-si, Bohyeonsan Mt., 09 Jul 2019, H. J. Jo et al. HJ190709-003, 004 (ANH); Yeongju-si, Sobaeksan Mt., 24 Jun 1989, J. S. Lee KUSA200407272034 (KH); Yeongyang-gun, Cheonggi-myeon, Cheonggi Lake, 12 Jun 2020, H. J. Jo et al. HJ200612-001 (ANH); Yeongyang-gun, Irwolsan Mt., 1 Jul 1987, Y. K. Jang KBNA200007241026 (KH). Jeollabuk-do: Muju-gun, Deokyusan Mt., 23 Jun 1985, J. Y. Won KUSA200407272031 (KH). Pyeonganbukdo: Gang gye-si, 4 Jul 1914, ? 5944 (TI). Pyeongannam-do: Dalgoksan Mt., 8 Aug 1973, J. Satotu s.n. (TI). ?, 15 Sep 1973, J. Satotu s.n. (TI).

4. Boehmeria spicata. CHINA. Shanxi: Yuanchu, Yechoshan, 24 Jul 1918, H. Smith 6373 (TI).

JAPAN. Honshu: Gunma Pref., Tano-gun, Onishimachi, Hokku, 11 Aug 1976, J. Murata 2620 (TI); Kanagawa Pref., Yamakita, Takamatsuyama Mt., Nov 1958, Y. Asai 7488 (TI); Kouchi Pref., Kubokawa Town, Moriga-Uchi, 9 Oct 2003, T. Miyazaki 310205 (TI); Kouchi Pref., Nakatosa Town, Yamauchi, 4 Oct 2003, T. Miyazaki 310031 (TI); Shizuoka Pref., Gotemba City, Ashitaka Mt., 6-7 Oct 1982, T. Yahara \& T. Kubo 6475 (TI); Tokyo Pref., Takaosan Mt., 12 Aug 1979, K. Iijima 1334599 (TI); Shikoku: Ehime Pref., Higashi-akaishi Mt., 14 Sep 1981, T. Yahara 5823 (TI); Kochi Pref., Agawa village, Nakatu Mt., 13 Aug 2003, T. Miyazaki 308031 (TI); Kochi Pref., Ooishi, Motoyama Town, Nagaoka Country, 28 Jul 2003, T. Hosokawa 609260 (TI); Kochi Pref., Sugenoue, Kitagawamura, Aki-gun, 5 Oct 2003, N. Kurosaki 23885 (TI); Kochi Pref., Takaoka District, Natatosa Town, Yaiga, 15 Nov 2004, T. Miyazaki 411219 (TI); Kochi Pref., Takaoka District, Shimanto Town, Shiwamine, 1 Nov 2010, T. Miyazaki 1011240 (TI).

KOREA. Chungcheongbuk-do: Danyang-gun, Jungnyeongjae, 5 Sep 2016, H. J. Jo et al. HJ160905-001, 002 (ANH); Cheongyang-gun, Jeongsan-myeon, Yongdu-ri, 11 Aug 2016, H. J. Jo et al. HJ160811-002 (ANH); Cheongyang-gun, Chilgapsan Mt., Dorim Valley, 09 Jun 2016 , H. J. Jo et al. HJ160609-001, 002 (ANH); Cheongyang-gun, Chilgapsan Mt., Dorim Valley, 11 Aug 2016, H. J. Jo et al. HJ160811-001 (ANH); Gongju-si, Yugu-eup, Sedong-ri, 29 Jun 2017, H. J. Jo et al. HJ170629-001 (ANH); Hongseong-gun, Oseosan Mt., ?, H. C. Chung \& H. S. Chung s.n. (KH); Sacheon-si, Waryongsan Mt., 16 Oct 1999, N. S. Lee \& S. Yeou 1524 (KH). Daegu-si: Dalseong-gun, Choejeongsan Mt., 4 Oct 2019, H. J. Jo et al. HJ191004-003 (ANH); Dong-gu, Palgongsan Mt., 28 May 2005, Y. H. Son KNU00042658 (KH). Gangwon-do: Goseonggun, Toseong-myeon, Hwaam Temple, 23 Sep 2016, H. J. Jo et al. HJ160923-001 (ANH); Inje-gun, Seoraksan Mt., 20 Jun 2016, H. J. Jo et al. HJ160620-002 (ANH); Inje-gun, Seoraksan Mt., 19 Jul 1936, T. Nakai 17362 (TI). Gyeongsangbuk-do: Andong-si, Gallasan Mt., 9 Aug 2016, H. J. Jo et al. HJ160809-001 (ANH); Bonghwa-gun, Baebawisan Mt., 22 Jul 2019, H. J. Jo et al. HJ190722-001 (ANH); Bonghwa-gun, Cheongnyangsan Mt., 17 Aug 2016, H. J. Jo et al. HJ160817-003, 005 (ANH); Cheongsong-gun, Budong-myeon, Cheongsongeoreum Valley, 18 Jul 2016, H. J. Jo et al. HJ160718-001, 002 (ANH); Cheongsong-gun, Budong-myeon, Eoreum Valley, 15 Jun 2016, H. J. Jo et al. HJ160615001 (ANH); Chilgok-gun, Gasansanseong, 25 Sep 2019, H. J. Jo et al. HJ190925-002 (ANH); Gimcheon-si, Samdobong Mt., 21 Aug 2019, H. J. Jo et al. HJ190821-004 (ANH); Mungyeong-si, Joryeongsan Mt., 3 Jun 2016, H. J. Jo et al. HJ160603-002 (ANH); Pohang-si, Songnamyeonm, Malmeorisan Mt., 29 May 2020, H. J. Jo et al. HJ200529-001 (ANH); Ulleung-gun, 17 Aug 1992, W. T. Lee s.n. (TI); Ulleung-gun, Dodong-ri, Seonginbong Mt., 30 Jul 2019, H. J. Jo et al. HJ190730-003, 004 (ANH); Ulleung-gun, Seonginbong Mt., 17 Jun 2016, H. J. Jo et al. HJ160617-002, 003 (ANH); Ulleung-gun, Naribunji, 17 Oct 2016, H. J. Jo et al. HJ161017-001, 002 (ANH); Ulleung-gun, Ulleung-eup, Dodong-ri, Bongnae Falls, 18 Oct 2016, H. J. Jo et al. HJ161018-004 (ANH); Yeongcheon-si, Bohyeonsan Mt., 16 Aug 2019, H. J. Jo et al. HJ190816-001, 002 (ANH). Gyeongsangnam-do: Goseong-gun, Yeonhwasan Mt., 16 Jul 2019, H. J. Jo et al. HJ190716-002 (ANH); Goseonggun, Yeonhwasan Mt., 20 Aug 2019, H. J. Jo et al. HJ190820-002 (ANH); Hanmyang-gun, Jirisan Mt., 31 Jul 1971, Y. L. Lee 2820 (KH); Hapcheon-gun, Gayasan Mt., 28 Jul 2016, H. J. Jo et al. HJ160728-001-003 (ANH); Hapcheon-gun, Gayasan Mt., 9 Sep 2006, H. T. Im et al. 64629 (TI); Jinhae-gun, 8 May 1928, T. Nakai 11096 (TI); Sacheon-si, Waryong Village, 9 Oct 2018, H. J. Jo et al. HJ181009-001 (ANH); Sacheon-si, Yonggang-dong, Yongdu Park, 23 Aug 2016, H. J. Jo et al. HJ160823-001 (ANH); Sancheong-gun, Jirisan Mt., 13 Jul 2016, H. J. Jo et al. HJ160713-002 (ANH). Hwanghae-do: Daecheongdo Island, 26 Jul 1929, T. Nakai 12676 (TI); ?, 25 Aug 1943, ? s.n. (TI); ?, 26 Aug 1941, ? s.n. (TI). Jeju-do: Jeju-si, Aewol-eup, Musucheon, 27 Jul 2016, H. J. Jo et al. HJ160727-001-003 (ANH); Hallasan Mt., 31 Jul 2012 , C. M. Kang et al. 10019669 (WFRC); Seogwipo-si, Doneori Oreum, 21 Aug 2012, G. R. Kim et al. 10020307 (WFRC); Seogwipo-si, Hannamri, 3 Aug 2010, J. E. Kim et al. 10014231 (WFRC); Seogwipo-si, Meochewat Forest Road, 27 Jul 2016, H. J. Jo et al. HJ160727-007 (ANH); Seogwipo-si, Saekdal-dong, 1100goji, 27 Jul 2016, H. J. Jo et al. HJ160727-006 (ANH); Seogwipo-si, Sillye-ri, 5 Aug 2010, M. K. Chang \& S. C. Hong 10014301 (WFRC). Jeollabuk-do: Jinan-gun, Unjangsan Mt., 17 Jul 2016, H. J. Jo et al. HJ160717-001 (ANH); Jinan-gun, Unjangsan Mt., 17 Jul 2016, H. J. Jo et al. HJ160717-002-005 (ANH); Sunchang-gun, Hoemunsan Mt, 6 Aug 2019, H. J. Jo et al. HJ190806-008 (ANH). Jeollanam-do: Gurye-gun, Jirisan Mt., Nogodan, 21 Aug 1982, F. Yamazaki 3210 (TI); Hadong-gun, Hadong Lake, 13 Jul 2016, H. J. Jo et al. 
HJ160713-001 (ANH); Yeosu-si, Hwangsaebong Mt., 2 Sep 2019, H. J. Jo et al. HJ190902-004 (ANH); Yeosu-si, Hwangsaebong Mt., 23 Jun 2020, H. J. Jo et al. HJ200623-001 (ANH). Seoul-si: ?, 13 Jun 1981, G. S. Chung SKKA200007191114 (KH). ?, Sep 1911, ? 5967 (TI); ?, 1912 , T. Mori s.n. (TI); ?, 22 Sep 1915, T. Nakai 9979 (TI); ?, 3 Aug 1938, T. Nakai 16011 (TI). 